\title{
Palichnology of the Lower Devonian Wapske Formation, Perth-Andover- Mount Carleton region, northwestern New Brunswick, eastern Canada
}

\author{
Yaojun Han* and Ron K. Pickerill \\ Department of Geology, University of New Brunswick, Fredericton, New Brunswick E3B 5A3, Canada
}

\author{
Date Received December 13, 1994 \\ Date Accepted February 7, 1995
}

\begin{abstract}
The Lower Devonian Wapske Formation of the Tobique Group in the Perth-Andover-Mount Carleton region of northwestern New Brunswick forms part of the tectonostratigraphic Tobique Zone. In this region, the formation is 4000 to $9000 \mathrm{~m}$ thick and is interpreted as deep-marine turbiditic in origin. Seven sedimentary facies are recognized. These are: conglomerate facies (Facies 1); massive and parallel-laminated sandstone facies (Facies 2); thin- to thick-bedded sandstone with minor mudstone interbeds and/or mud-capped facies (Facies 3); thin-bedded sandstone and mudstone facies (Facies 4); thin-bedded, graded, fine-grained sandstone facies (Facies 5); thin-bedded, fine-grained sandstone and silty mudstone facies (Facies 6); and thin- and medium-bedded siltstone and mudstone facies (Facies 7). These facies are grouped into five facies associations reflecting a deep-marine fan system consisting of distributary channels, depositional lobes, lobe or fan fringes, and interchannel areas associated with a basin plain.

A relatively diverse and well-preserved ichnofauna, consisting of 23 ichnogenera (41 ichnospecies) and three vernacular ichnotaxa, is systematically described, these comprising Arthraria Billings, 1872; Bergaueria Prantl, 1945; Chondrites von Sternberg, 1833; Cochlichnus Hitchcock, 1858; Cosmorhaphe Fuchs, 1895; Cruziana d'Orbigny, 1842; Dendrotichnium Häntzschel, 1975; Didymaulichnus Young, 1972; Helminthoida Schafhäutl, 1851; Helminthopsis Heer, 1877; Hormosiroidea Schaffer, 1928; Monomorphichnus Crimes, 1970; Neonereites Seilacher, 1960; Palaeophycus Hall, 1847; Paleodictyon Meneghini in Murchison, 1850; Phycodes Richter, 1850; Prolopaleodictyon Ksiaźkiewicz, 1970; Protovirgularia M'Coy, 1850; Rusophycus Hall, 1852; Skolithos Haldeman, 1840; Taenidium Heer, 1877; Uchiriles Macsotay, 1967; Umfolozia Savage, 1971; two track forms and indeterminate scratch markings. Their palaeoenvironmental distribution within the sequence correlates well with the interpreted submarine fan complex and compares favourably with other previously documented ichnofaunas from deep-marine fans. Collectively, the ichnofauna of the Wapske Formation is characteristic of Seilacher's (1967) Nereites ichnofacies.
\end{abstract}

La formation de Wapske du Dévonien inférieur du groupe de Tobique dans la région de Perth Andover/mont Carleton du nord-ouest du Nouveau-Brunswick fait partie de la zone tectonostratigraphique de Tobique. Dans cette région, la formation a 4000 à $9000 \mathrm{~m}$ d'épaisseur et elle est interprétée comme une formation d'origine turbiditique abyssale. On reconnaît sept faciès sédimentaires, notamment : le conglomérat (faciès 1); un faciès de grès laminé massif et parallèle (faciès 2); un faciès de grès en couches épaisses ou minces interstratifié de mudstone en quantité mineure ou couronné de boue (faciès 3 ); un faciès de mudstone et de grès en couches minces (faciès 4 ); un faciès de grès à grains fins, profilé, en couches minces (faciès 5); un faciès de mudstone vaseux et de grès à grains fins, en couches minces (faciès 6); et un faciès de mudstone et de microgrès en couches minces et moyennes. Ces faciès sont groupés en cinq associations de faciès correspondant à un système en éventail abyssal constitué de défluents, de lobes sédimentaires, de franges en lobe ou en éventail et de zones inter-canaux associées à une plaine synclinale.

Une ichnofaune relativement diversifiée et bien préservée, constituée de 23 ichnogenres (41 ichnoespèces) et trois ichnotaxa courants, est décrite de façon systématique. Ceux-ci comprennent l'Arthraria Billings, 1872; le Bergaueria Prantl, 1945; les Chondrites von Sternberg, 1833; le Cochlichnus Hitchcock, 1858; le Cosmorhaphe Fuchs, 1895; le Cruziana d'Orbigny, 1842; le Dendrotichnium Hantzschel, 1975; le Didymaulichnus Young, 1972; l'Helminthoida Schafhautl, 1851; l'Helminthopsis Heer, 1877; l'Hormosiroidea Schaffer, 1928; le Monomorphichnus Crimes, 1970; le Neonereites Seilacher, 1960; le Palaeophycus Hall, 1847; le Palaeodictyon Meneghini dans Murchison, 1850; le Phycodes Richter, 1850; le Prolopaleodictyon Książiewicz, 1970; le Protovirgularia M'Coy, 1850; le Rusophycus Hall, 1852; le Skolithos Haldeman, 1840; le Taenidium Heer, 1877; l'Uchirites Macsotay, 1967; l'Umfolozia Savage, 1971; deux formes de pistes et des marques de grattage. Leur répartition paléoenvironnementale à l'intérieur de la séquence correspond bien avec le complexe en éventail sous-marin interprété et elle se compare favorablement avec les autres ichnofaunes des éventails abyssaux documentées auparavant. Collectivement, l'ichnofaune de la formation de Wapske est caractéristique de l'ichnofaciès Nereites de Seilacher (1967).

[Traduit par la rédaction]

\section{INTRODUCTION}

The study area is located in northwestern New Brunswick, eastern Canada, from Perth-Andover to Mount Carleton, a distance of approximately $93 \mathrm{~km}$, and is part of the

*Present address: Department of Geology, University of Alberta, Edmonton, Alberta T6G 2E3, Canada tectonostratigraphic Tobique Zone (Fig. 1) (St. Peter, 1978a, 1979; Pickerill, 1986, 1991; Wilson, 1990). In this area, the Lower Devonian (Lochkovian-Pragian) Wapske Formation of the Tobique Group, the subject of this contribution, underlies approximately $205 \mathrm{~km}^{2}$ and has been estimated by St. Peter (1978a,b, 1979) to be between 4000 and $9000 \mathrm{~m}$ in thickness. 


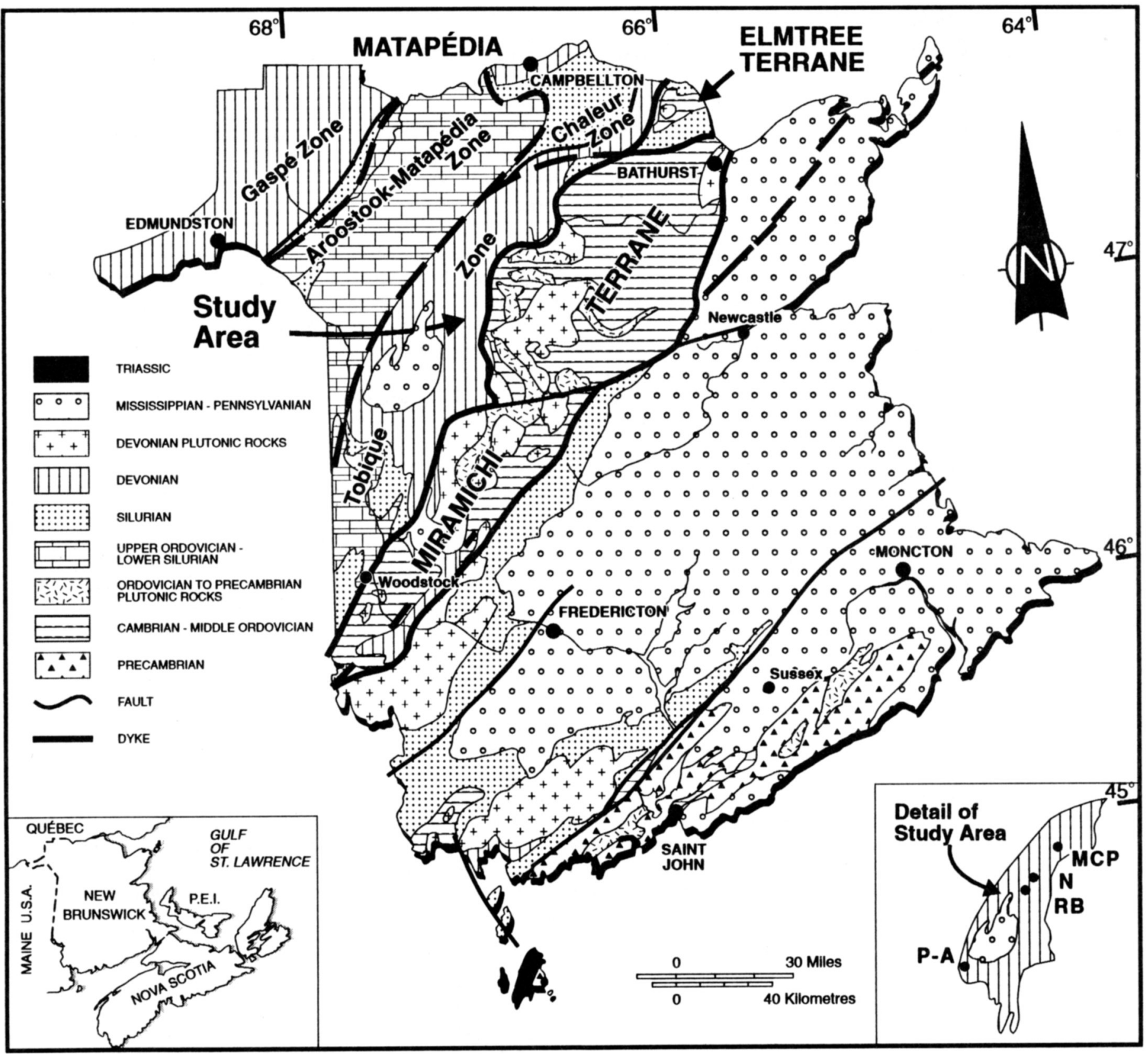

Fig. 1. Generalized tectonostratigraphic map of New Brunswick, eastern Canada, showing location of the study area (modified from Pickerill, 1986; Fyffe and Fricker, 1987; Wilson, 1990). P-A = Perth-Andover; RB = Riley Brook; $\mathrm{N}=$ Nictau; MCP = Mount Carleton Park.

Surficial exposure, however, is restricted essentially to roadsides in the Riley Brook, Nictau, Mount Carleton Provincial Park and Perth-Andover districts (Fig. 1). The most common sedimentary lithofacies are grey, greenish grey or green siltstones interbedded with varying proportions of grey, greenish grey and brown, fine- to medium-grained sandstones and mudstones or shales.

Several authors (e.g., St. Peter, 1978b, 1979, 1981, 1982; Skinner, 1982; Irrinki and Crouse, 1986) have proposed a relatively shallow marine, quiet water depositional setting for the Wapske Formation, based essentially on the evidence of its contained faunal communities (see also Boucot and Wilson, 1994). However, an alternative scenario was envisaged by Pickerill $(1986,1991)$ who, on sedimentological and taphonomic considerations, interpreted the formation as having been deposited below storm wave base in an outer shelf-upper slope depositional environment. In this paper we briefly assess the sedimentology of the Wapske Formation in more detail than in Pickerill $(1986,1991)$ and, in particular, describe systematically its contained ichnotaxa.

Ichnological research within the adjacent tectonostratigraphic Aroostook-Matapédia Zone has been conducted by Pickerill $(1980,1981,1987)$ and Pickerill et al. (1987), but essentially on strata of Late Ordovician and Early Silurian age. The ichnology of the Lower Devonian Wapske Formation, until now, remains unstudied, except for a short ichnotaxonomic commentary by Pickerill (1991) and a series of more detailed ichnotaxonomic studies by Han and Pickerill (1994a,b, 1995). Most strata of the Tobique Group in the study area lack body fossils; however, many beds contain relatively well-preserved 
and abundant ichnofossils that are considered useful for palaeoenvironmental interpretation, particularly in view of the fact that such previous interpretations of the sequence are at considerable variance. The purpose of this contribution is therefore to describe the ichnofaunas from this region and to comment on their interpreted palaeoenvironmental context.

\section{STRATIGRAPHY AND SEDIMENTOLOGY}

The Lower Devonian Tobique Group was originally proposed to comprise a basal Costigan Mountain Formation and a conformably overlying Wapske Formation (St. Peter, 1978b) (Table 1). The constituent lithotypes in these formations are similar, although the relative proportions differ, the Costigan Mountain Formation being dominated by volcanic rocks and the Wapske Formation by siliciclastic strata. Initially, St. Peter (1978b) believed that the contact between these formations was probably isochronous; however, faunal evidence later indicated that the Wapske Formation is locally intercalated and coeval with the Costigan Mountain Formation (St. Peter, 1979, 1981) and thus that the contact should be regarded as diachronous.
Faunal evidence, as recently reviewed in Boucot and Wilson (1994), suggests an earliest Lochkovian to latest Pragian age for the Wapske Formation.

Seven sedimentary lithofacies have been recognized in the Wapske Formation in the present study. These lithofacies, individually differentiated on the basis of lithology, bed thickness, sandstone/mudstone ratios, bed geometry and contacts and internal sedimentary structures, are summarized in Table 2 . They are very similar to several of the seven submarine fan facies first proposed and described by Mutti and Ricci Lucchi (1972) and subsequently refined by Walker and Mutti (1973) and Ricci Lucchi $(1975 a, b)$. Associations of these sedimentary facies are interpreted as representing particular depositional environments present in a deep-water submarine fan system. These lithofacies, their associations and depositional subenvironments will be described separately (Han and Pickerill, in preparation) but are currently available in Han (1995). For brevity, however, the characteristics of these subenvironments, based on our interpretations of individual facies associations, can be summarized as follows.

Mid-fan distributary channels comprise massively bedded,

Table 1. Summary of lithostratigraphy and previously interpreted depositional environments of the Tobique Group. Numbers refer to: 1, Wilson, 1990. 2, Skinner, 1982. 3, Irrinki and Crouse, 1986. 4,5,6 and 7, St. Peter, 1978b, 1979, 1981 and 1982. 8, Pickerill, 1986.

\begin{tabular}{|c|c|c|c|c|}
\hline System & Group & Formation & Lithologies & $\begin{array}{c}\text { Depositonal } \\
\text { Environments }\end{array}$ \\
\hline Devonian & & & Gabbro and granite & \\
\hline \multirow[t]{2}{*}{$\begin{array}{c}\text { Lower } \\
\text { Devonian }\end{array}$} & \multirow[t]{2}{*}{ Tobique } & \multirow{2}{*}{ la } & $\begin{array}{l}\text { Sedimentary Unit: grey to green, quartzose or } \\
\text { argillaceous siltstone and fine- to medium-grained } \\
\text { calcareous to non-calcareous, micaceous, } \\
\text { quartzose to arkosic, sandstone; minor grey to } \\
\text { green shale and slate; } \\
\text { Basaltic Unit: green-grey basalt; minor diabase } \\
\text { sills and dykes, slate, greywacke and rhyolites; }\end{array}$ & $\begin{array}{l}1,3: \text { shallow water marine. } \\
2,4,5,6,7 \text { : terrestrial and } \\
\text { shallow water marine. } \\
\text { 8: outer shelf-upper slope } \\
\text { deep water marine. }\end{array}$ \\
\hline & & & $\begin{array}{l}\text { Unit 1: pink, red and grey rhyolite, quartz-feldspar } \\
\text { porphyry flows, tuffs, and pyroclastic breccia. } \\
\text { Unit 2: grey shale, argillite and greywacke; minor } \\
\text { diabase, rhyolite and basalt. } \\
\text { Unit 3: green-grey basalt flows and tuffs, minor } \\
\text { volcanogenic sediments and conglomerate. }\end{array}$ & $\begin{array}{l}1,4,6 \text { : terrestrial to shallow } \\
\text { water marine. }\end{array}$ \\
\hline \multirow[t]{2}{*}{ Silurian } & \multirow[t]{2}{*}{ Perham } & Chambord Bk. & Grey to pink limestone; red-brown silty limestone. & 1,8: shallow marine shelf. \\
\hline & & Hazeldean & Grey to green siltstone and sandstone,minor shale. & 1,8: shallow marine shelf. \\
\hline
\end{tabular}


Table 2. Summary of lithofacies of the Wapske Formation and their essential characteristics.

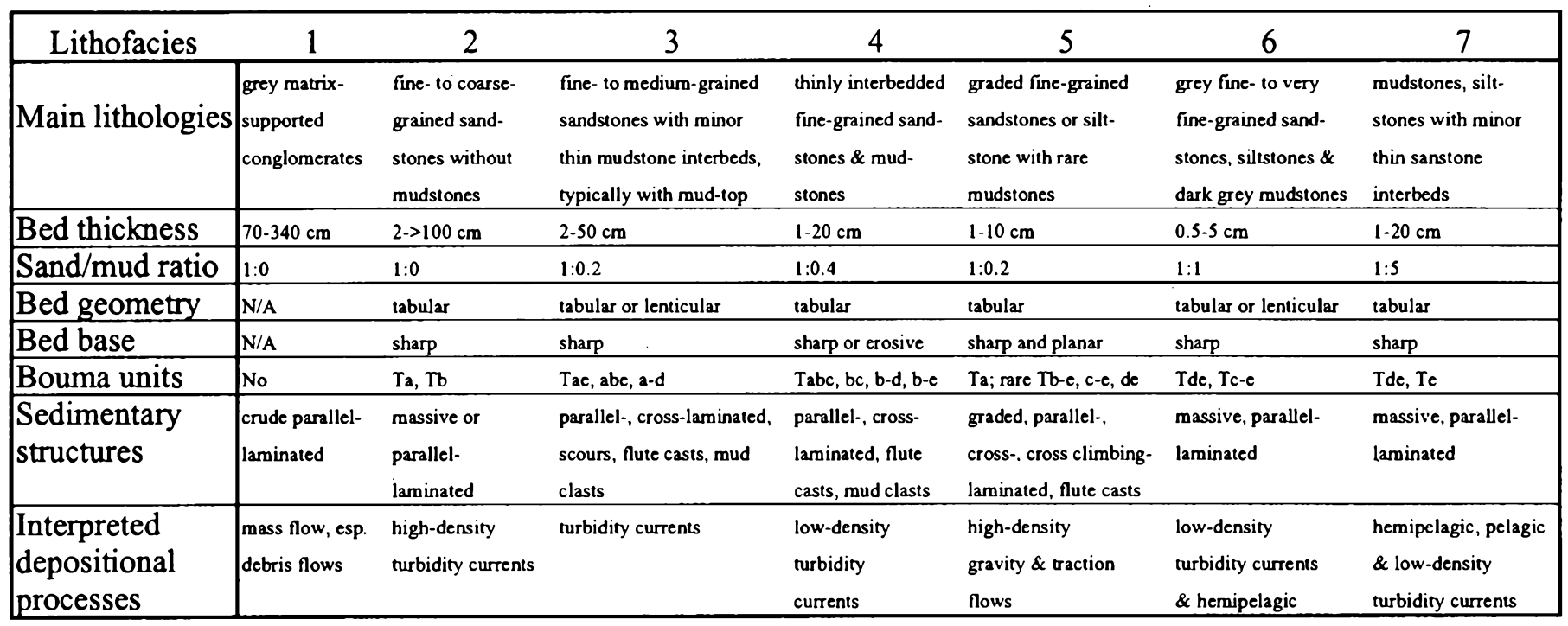

matrix-supported conglomerates (Facies 1) that only rarely crop out in the study area. Clasts are dispersed within a muddy or silty matrix.

Mid-fan depositional lobes consist of thin-bedded, finegrained, graded sandstones or coarse-grained siltstones (Facies 5 ), in association with thin- to medium-bedded fine-grained sandstones interbedded with mudstones (Facies 4), mediumgrained mud-capped sandstones (Facies 3 ) and rare mediumto thick-bedded, medium-grained, massive and parallel-laminated sandstones (Facies 2). Facies 2 is generally restricted to upper parts of individual sequences in which the thin-bedded, fine-grained sandstone beds are dominant. Thickening and coarsening upward cycles, high sandstone/mudstone ratios and laterally continuous beds are characteristic of this subenvironment.

Outer fan lobes or fan fringes are dominated by thin-bedded sandstones and mudstones (Facies 4 ) accompanied by mudstones and graded fine-grained sandstones. Beds within these sequences exhibit a thinning and fining upward tendency.

Interchannel deposits consist of thin-bedded (with rare medium-bedded), fine-grained, graded sandstones (Facies 5). Amalgamation of sandstone beds is very common. Interbedded sandstones and mudstones (Facies 4), mudstones (Facies 7), and thinly interbedded sandstones and mudstones (Facies 6) are also present. The sequences show a thinning or minor thickening upward trend.

Basin plain-distal outer fan associations are characterized by laterally continuous thin-bedded mudstones and silty mudstones with thin, fine-grained sandstone interbeds (Facies 7); mud-capped sandstones (Facies 3 ) may be locally present. No specific cyclical sequences occur.

Within the proposed deep-water submarine fan system, the precise location of the actual feeder channel(s) of the submarine fan(s) cannot be assessed. However, it is likely that the source was located to the east or southeast of the present study area, as most conglomerates (Facies 1) are present there and palaeocurrent indicators such as flutes and cross-lamination suggest a west-northwest direction of turbidity current flow. The rare presence of coarse-grained channelized deposits, and com- mon occurrence of thin- to medium-bedded, laterally continuous sandstones and mudstones suggest that the overall depositional environment was probably that of a mid or outer fan region of a deep-sea fan complex.

\section{Palaeoenvironmental distribution OF TRACE FOSSILS}

Ichnofaunas in the Wapske Formation are represented by horizontal fodinichnia, pascichnia, agrichnia and fewer repichnia, and were produced by unknown representatives of both deposit- and suspension-feeders (Table 3 ). The ichnotaxa, comprising 23 ichnogenera, are collectively characteristic of the deep-water Nereites ichnofacies of Seilacher (1967) (Fig. 2). The ichnofauna is relatively diverse and abundant with Helminthopsis and Palaeophycus representing most trace fossils. Graphoglyptids (notably Paleodictyon, Protopaleodictyon, Cosmorhaphe) and pascichnia (such as Helminthopsis, Helminthoida, Uchirites, Palaeophycus) dominate the pre-depositional ichnocoenosis. In contrast, fodinichnia (especially Chondrites), domichnia (e.g., Bergaueria, Skolithos) and repichnia (such as Umfolozia, Protovirgularia, Cruziana) typify the postdepositional ichnocoenosis. Collectively, the overall ichnofaunal assemblage of the Wapske Formation is comparable to several of those recorded from other deep-marine fans (see McCann and Pickerill, 1988; Miller, 1991, 1993; Crimes and Crossley, 1991; Crimes et al., 1992; Crimes and Fedonkin, 1994; and references therein). This is consistent with our sedimentological interpretations that suggest that deposition of the formation occurred in a deep-marine environment.

The most important parameters governing the distribution of deep-marine organisms are sediment texture, energy levels, substrate consistency and stability, oxygen levels at or immediately below the sediment-water interface, availability of food, sedimentation rates and frequency of event deposition. The palaeoecological controls over ichnofacies have been extensively discussed (e.g., Crimes, 1970a; Kern and Warme, 1974; Corbo, 1979; Frey and Seilacher, 1980; Pickerill et al., 1984; Bromley et al., 1984; Ekdale, 1985; Fillion and Pickerill, 1990; Uchman, 
Table 3. Characteristics of ichnotaxa from the Wapske Formation.

\begin{tabular}{|c|c|c|c|c|c|c|c|c|}
\hline Ichnotaxa & $\mathrm{D}$ & $\mathrm{S}$ & $\mathrm{F}$ & Feeding & Ethology & Toponomy & $\mathrm{N}$ & Pre-/Post- \\
\hline Arthraria antiquata & & & $\mathrm{T}$ & Filter & Fo & $\mathrm{CXH}$ & $\mathrm{R}$ & $?$ \\
\hline Bergaueria hemispherica & M & $\mathrm{T}$ & & ?Filter & $\mathrm{Cu} / \mathrm{Dm}$ & EN & $\mathrm{C}$ & Post- \\
\hline B. aff. perata & $M$ & $\mathrm{~T}$ & & ?Filter & $\mathrm{Cu} / \mathrm{Dm}$ & EN & $\mathrm{R}$ & Post- \\
\hline Chondrites furcatus & & & $\mathrm{T}$ & Deposit & Fo & EN & $C$ & Post- \\
\hline C. targionii & & & $\mathrm{T}$ & Deposit & Fo & EN & $\mathrm{R}$ & Post- \\
\hline Chondrites isp. form A & & & $\mathrm{T}$ & Deposit & Fo & $\mathrm{CXH}$ & $\mathrm{R}$ & $?$ \\
\hline Chondrites isp. form $B$ & & & $\mathrm{~T}$ & Deposit & Fo & $\mathrm{CXH}$ & $\mathrm{R}$ & Post- \\
\hline Cochlichnus anguineus & & & $\mathrm{T}$ & Deposit & $\mathrm{Rp}$ & $\mathrm{CXH}$ & $\mathrm{R}$ & $?$ \\
\hline Cosmorhaphe fuchsi & $\mathrm{T}$ & & & Deposit & Ps & $\mathrm{CXH}$ & $\mathrm{R}$ & Pre- \\
\hline C simuosa & $\mathrm{T}$ & & & Deposit & Ps & $\mathrm{CXH}$ & $\mathrm{C}$ & Pre- \\
\hline Cruziana problematica & M & $\mathrm{T}$ & & Deposit & $\mathrm{Rp}$ & $\mathrm{CXH}$ & $C$ & Pre- \\
\hline Dendrotichnium haentzscheli & $\mathrm{T}$ & & & Deposit & Fo & $\mathrm{CXH}$ & $\mathrm{R}$ & $?$ \\
\hline Didymaulichmus lyelli & & & $\mathrm{T}$ & Deposit & $\mathrm{Rp} / \mathrm{Ps}$ & $\mathrm{CXH}$ & $\mathrm{R}$ & $?$ \\
\hline Helminthoida cf. labyrinthica & $\mathrm{T}$ & & & Deposit & Ps & $\mathrm{CXH}$ & $\mathrm{R}$ & Pre- \\
\hline H. miocenica & $\mathrm{T}$ & & & Deposit & Ps & $\mathrm{CXH}$ & $c$ & Pre- \\
\hline Helminthopsis abeli & $\mathrm{T}$ & & M & Deposit & Ps & $\mathrm{CXH}$ & A & Pre- \\
\hline$H$ cf. gramulata & $\mathrm{T}$ & & M & Deposit & Ps & $\mathrm{CXH}$ & $A$ & Pre- \\
\hline H. hieroglyphica & $\mathrm{T}$ & & M & Deposit & Ps & $\mathrm{CXH}$ & $\mathrm{R}$ & Pre- \\
\hline Helminthopsis isp. & $\mathrm{T}$ & & M & Deposit & Ps & $\mathrm{CXH}$ & A & Pre- \\
\hline Hormosiroidea cf. beskidensis & & & $\mathrm{T}$ & $?$ & $\mathrm{Rp}$ & $\mathrm{CXH}$ & $C$ & ?Pre- \\
\hline Monomorphichmus multilineatus & & $\mathrm{T}$ & & - & $\mathrm{Rp} / \mathrm{Ps}$ & $\mathrm{CXH}$ & $\mathrm{R}$ & ?Post- \\
\hline Neonereites biserialis & & & $\mathrm{T}$ & Deposit & Ps & $\mathrm{CXH}$ & $c$ & Post- \\
\hline N. multiserialis & $\mathrm{T}$ & & & Deposit & Ps & $\mathrm{CXH}$ & $\mathrm{A}$ & Post- \\
\hline N. uniserialis & & & $\mathrm{T}$ & Deposit & Ps & $\mathrm{CXH}$ & c & Post- \\
\hline Palaeophycus heherti & & & $\mathrm{T}$ & ?Filter & Ps & $\mathrm{CXH}$ & $C$ & Pre- \\
\hline P. striatus & & & $\mathrm{T}$ & ?Filter & Ps & $\mathrm{CXH}$ & C & Pre- \\
\hline F. tubularis & & & $T$ & ?Filter & Ps & $\mathrm{CXH}$ & A & Pre- \\
\hline F'alaeophycus isp. & & & $\mathrm{T}$ & ?Filter & Ps & $\mathrm{CXH}$ & A & Pre- \\
\hline Faleodictyon isp. & $\mathrm{T}$ & M & & Deposit & $\mathrm{Ag}$ & $\mathrm{CXH}$ & $c^{\prime}$ & Pre- \\
\hline Fhycodes flabellus & & & $\mathrm{T}$ & Deposit & Fo & $\mathrm{CXH}$ & $C$ & Post- \\
\hline P. palmatus & & & $\mathrm{T}$ & Deposit & Fo & $\mathrm{CXH}$ & $C^{\prime}$ & Post- \\
\hline P. aff palmatus & & & $\mathrm{T}$ & Deposit & Fo & $\mathrm{CXH} / \mathrm{EN}$ & $\mathrm{R}$ & Post- \\
\hline P. pedum & & & $\mathrm{T}$ & Deposit & Fo & $\mathrm{CXH}$ & $c$ & Post- \\
\hline P. templus & & & $\mathrm{T}$ & Deposit & Fo & $\mathrm{CXH}$ & A & Post- \\
\hline Protopaleodictyon incompositum & $\mathrm{T}$ & M & & Deposit & $\mathrm{Ag}$ & $\mathrm{CXH} / \mathrm{COH}$ & $\mathrm{R}$ & Pre- \\
\hline Protovirgularia dichotoma & $\mathrm{T}$ & M & & Deposit & $\mathrm{Rp} / \mathrm{Fo} ?$ & $\mathrm{CXH}$ & A & ?Post- \\
\hline Rusophycus cf. carbonarius & & $\mathrm{T}$ & M & Deposit & $\mathrm{Cu}$ & $\mathrm{CXH}$ & $\mathrm{R}$ & Pre- \\
\hline Skolithos linearis & $\mathrm{M}$ & $\mathrm{T}$ & & Filter & $\mathrm{Dm}$ & EN & A & Post- \\
\hline Taenidium serpentimum & M & $\mathrm{T}$ & & Deposit & $\mathrm{Fo} / \mathrm{Ps}$ & $\mathrm{CXH}$ & $\mathrm{R}$ & Post- \\
\hline Uchirites implexus & & & $\mathrm{T}$ & Deposit & $\mathrm{Rp} / \mathrm{Ps}$ & $\mathrm{CXH}$ & $C$ & Pre- \\
\hline Umfolozia cf. sinuosa & & $\mathrm{T}$ & & $?$ & $\mathrm{Rp}$ & NA & $\mathrm{R}$ & Post- \\
\hline
\end{tabular}

Key: $\mathrm{D}=$ deep-water preference, $\mathrm{S}=$ shallow-water preference, $\mathrm{F}=$ facies crossing $(\mathrm{T}=$ typical, $\mathrm{M}=$ minor); Ethology: $\mathrm{Ag}=\mathrm{agrichnia}, \mathrm{Cu}$ $=$ cubichnia, $\mathrm{Dm}=$ domichnia, Fo $=$ fodinichnia, $\mathrm{Ps}=$ pascichnia, $\mathrm{Rp}=$ repichnia; Toponomy: $\mathrm{CXH}=$ convex hyporelief, $\mathrm{COH}=$ concave hyporelief, $\mathrm{EN}=$ endorelief, $\mathrm{NA}=$ not available; $\mathrm{N}=$ number of trace fossils $(\mathrm{A}=$ abundant $(>10), \mathrm{C}=$ common $(3-10), \mathrm{R}=$ rare $(<3)$ ); PrePost- $=$ pre - and post-depositional origin. 


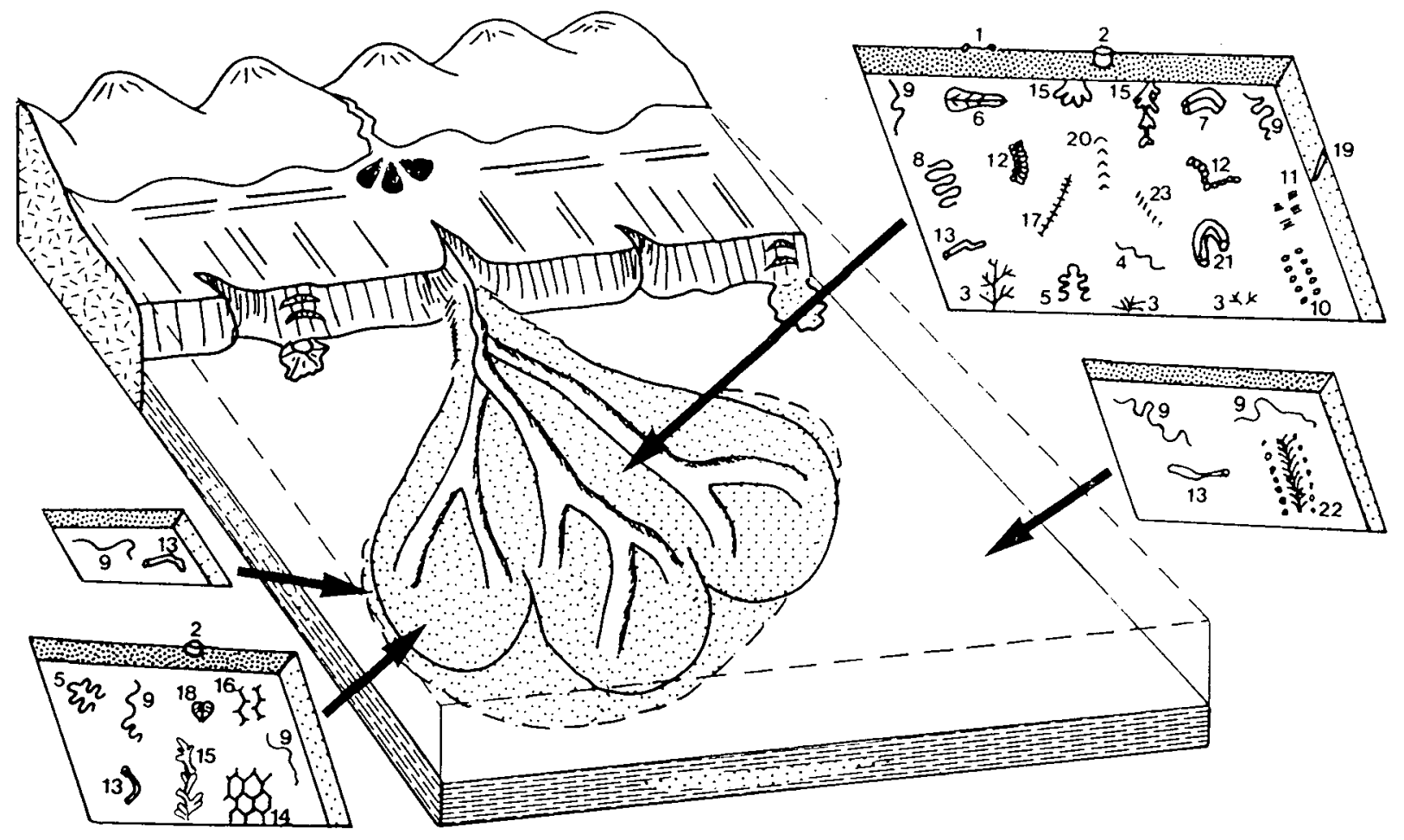

Fig. 2. Schematic representation showing distribution of the common trace fossils within the deep-sea fan of the Wapske Formation (no scale implied). Numbers represent: 1. Arthraria, 2. Bergaueria, 3. Chondrites, 4. Cochlichnus, 5. Cosmorhaphe, 6. Cruziana, 7. Didymaulichnus, 8. Helminthoida, 9. Helminthopsis, 10. Hormosiroidea, 11. Monomorphichnus, 12. Neonereites, 13. Palaeophycus, 14. Paleodictyon, 15. Phycodes, 16. Protopaleodictyon, 17. Protovirgularia, 18. Rusophycus, 19. Skolithos, 20. Taenidium, 21. Uchirites, 22. Track form B, 23. Scratch marks. Note: Track form A, Dendrotichnium haentzscheli and Umfolozia cf. sinuosa are not included as a result of their occurrence in small and isolated exposures that cannot be interpreted in terms of a specific palaeoenvironment (see also Table 4).

1992; Miller, 1993) and will not be repeated here. The palaeoenvironmental distribution of trace fossils in the Wapske Formation has been directed toward the interpreted depositional environments as determined by sedimentological analysis (Table 4) and is summarized below.

The distributary channel facies association is devoid of body fossils, trace fossils and bioturbation. The primary reasons for this are the coarse grain size and high-energy deposition, as well as the absence of shale interbeds precluding possible preservation of interface trace fossils.

The mid-fan depositional lobe facies association possesses a relatively diverse and abundant ichnocoenosis comprising traces produced by both suspension- and deposit-feeders that were responsible for the formation of cubichnia, domichnia, fodinichnia, pascichnia and agrichnia. The most common forms are horizontal agrichnia and pascichnia such as Cosmorhaphe, Helminthopsis, Palaeophycus, Paleodictyon and Protopaleodictyon, with fewer examples of cubichnia (Rusophycus), domichnia (Bergaueria) and fodinichnia (Phycodes). The relative abundance of agrichnia and pascichnia in the sequences is suggestive of a deep-water regime. The varied ethological groupings and the existence of both deposit- and suspension-feeding ichnofaunas suggest the presence of sufficient nutrient levels and adequate oxygenation both within the water column and at, or slightly below, the sediment-water interface. Most trace fossils are preserved in thinly interbedded, fine-grained sandstone and mudstone lithofacies (Facies 4), whereas associated lithofacies only exhibit Palaeophycus and Helminthopsis. Therefore, the sandstone and mudstone couplets are, in most examples, important with respect to toponomic preservation of trace fossils. The preservation of fine details in Palaeophycus striatus, Phycodes palmatus and Rusophycus cf. carbonarius indicates that the muds were relatively cohesive, as also suggested by the sharp burrow outlines of the associated ichnotaxa (cf. Fillion and Pickerill, 1990).

The lobe or fan fringe facies association contains the fewest number of ichnotaxa (excepting the distributary channel facies association). Helminthopsis and Palaeophycus are the only two types of traces found, being produced, respectively, by deposit- and suspension-feeders. Such a low diversity and abundance may not, however, be representative of the original ichnocoenoses, because lobe fringe deposits are not well represented in the sequence or, where present, are typically poorly exposed. Additionally, their component sandstones and/or siltstones are commonly amalgamated, without shale interbeds, thereby suggesting that surface and shallow traces may have been eroded by turbidity currents.

The interchannel facies association exhibits the most diverse and abundant ichnotaxa, comprising 18 ichnogenera and one unnamed form (36 ichnospecies), including vertical domichnia (Bergaueria and Skolithos), horizontal repichnia (Cochlichnus, Cruziana, Didymaulichnus, Hormosiroidea, Protovingularia and scratch marks), fodinichnia (Chondrites, Phycodes) and pascichnia (Cosmorhaphe, Helminthoida, Helminthopsis, Neonereites, Palaeophycus, Uchirites). The high diversity and abundance of deposit-feeding traces presumably reflects the existence of an abundant nutrient supply and sufficient oxygen levels to support a wide variety of infaunal and 
Table 4. Palaeoenvironmental distribution of trace fossils from the Wapske Formation.

\begin{tabular}{|c|c|}
\hline Environments & Ichnotaxa \\
\hline $\begin{array}{l}\text { Basin plain- } \\
\text { distal outer fan }\end{array}$ & $\begin{array}{l}\text { Helminthopsis abeli, } H . \text { isp., } \\
\text { Palaeophycus isp., Track form B }\end{array}$ \\
\hline Lobe fringes & $\begin{array}{l}\text { Helminthopsis isp., } \\
\text { Palaeophycus isp. }\end{array}$ \\
\hline $\begin{array}{c}\text { Depositional } \\
\text { lobes } \\
\text { in mid-fan }\end{array}$ & $\begin{array}{l}\text { Bergaueria hemispherica, } \\
\text { Cosmorhaphe fuchsi, } \\
\text { Helminthopsis abeli, } \\
\text { H. hieroglyphica, H. isp., } \\
\text { Palaeophycus striatus, P. isp., } \\
\text { Paleodictyon isp., Phycodes } \\
\text { templus, Protopaleodictyon } \\
\text { incompositum, Rusophycus cf. } \\
\text { carbonarius }\end{array}$ \\
\hline $\begin{array}{l}\text { Interchannel } \\
\text { areas }\end{array}$ & $\begin{array}{l}\text { Arthraria antiquata, Bergaueria } \\
\text { hemispherica, B. aff. perata, } \\
\text { Chondrites furcatus, } \\
\text { C. targionii, C. isp. form A and } \\
\text { B, Cochlichnus anguineus, } \\
\text { Cosmorhaphe fuchsi, C. sinuosa, } \\
\text { Cruziana problematica, } \\
\text { Didymaulichnus lyelli, } \\
\text { Helminthoida cf. labyrinthica, } \\
\text { H. miocenica, Helminthopsis } \\
\text { abeli, H. cf. granulata, } \\
\text { H. hieroglyphica, H. isp., } \\
\text { Hormosiroidea cf. beskidensis, } \\
\text { Monomorphichnus } \\
\text { multilineatus, Neonereites } \\
\text { biserialis, N. multiserialis, } \\
\text { N. uniserialis, Palaeophycus } \\
\text { heberti, P. striatus, P. tubularis, } \\
\text { P. isp., Phycodes flabellus, } \\
\text { P. palmatus, P. aff. palmatus, } \\
\text { P. pedum, P. templus, } \\
\text { Protovirgularia dichotoma, } \\
\text { Skolithos linearis, Taenidium } \\
\text { serpentinum, Uchirites implexus, } \\
\text { scratch marks }\end{array}$ \\
\hline
\end{tabular}

Note: Dendrotichnium haentzscheli, Umfolozia of. sinuosa and Track form $\mathrm{A}$ are not included as a result of their occurrence in small and isolated exposures that cannot be interpreted in terms of a specific palaeoenvironment (see also Fig. 2). epifaunal benthos. The occurrence of suspension feeders (domichnia) also suggests the existence of bottom currents carrying a continuous supply of suspended nutrients onto the sea floor. The preservation of surficial repichnia may reflect a reduced erosive capacity of turbidity currents and/or less intensive bioturbation by infaunal animals. Phycodes and the horizontal repichnia display sharp, and only rarely lined boundaries, thereby indicating a relatively cohesive muddy substrate (cf. Fillion and Pickerill, 1990). Interchannel deposits are characterized by thin-bedded sandstones and mudstones (Facies 4 ) and thin-bedded, fine-grained, graded sandstones (Facies 5), which provide ideal preservational conditions for the traces. From an environmental aspect, interchannel areas are more stable than channel, fan fringe and depositional lobe areas. In addition to preservational considerations, this could perhaps explain the presence of a presumably abundant and diverse epifauna and infauna. Crimes and Fedonkin (1994) recently concluded that interchannel areas associated with inner fans possessed diverse "shallow-water" trace fossils but fewer "deepwater" ichnotaxa, whereas those in outer fans had diverse "deepwater" trace fossils and a general absence of "shallow-water" trace fossils. Interchannel deposit sequences from the Wapske Formation exhibit mostly facies-crossing forms and more or less equal representatives of typical "shallow" and "deep" water forms.

The basin plain-distal outer fan facies association comprises essentially homogeneous muddy strata with sporadic turbidite sandstone interbeds. Exposed sequences reveal only isolated examples of Helminthopsis, Palaeophycus and unassigned tracks. The scarcity of ichnotaxa may reflect incomplete preservation of trace fossils because of the lack of turbidite sandstones as a casting medium, or may be a result of the environment being inimical to the support of a benthic population either as a result of low nutrient levels or depressed oxygen supplies at, or within, the upper levels of the surficial substrates.

In a general context, thin-bedded sandstones and siltstones contain considerably more ichnotaxa, both in terms of diversity and abundance, than do the thick-bedded turbidites, similar to analogous Cretaceous turbidites of northern California described by Miller (1993). The submarine fan system of the Wapske Formation appears to have contained sufficient food supplies and oxygen levels to support a widespread population of benthic organisms. However, oxygen levels in sediment below the sediment-water interface were at times presumably sufficiently reduced so that only the producer of Chondrites occurred in the sequence (see also Bromley and Ekdale, 1984; Hakes, 1985; Savrda and Bottjer, 1986). Secondary factors, such as mode of preservation and degree of exposure and weathering, also potentially influence the observed ichnocoenoses. In newly exposed outcrops where both talus and weathering processes are relatively minor, detailed examination and sampling of trace fossils was more difficult compared to outcrops with extensively exposed and weathered talus. For example, distributary channel deposits near Nictau Lake and depositional lobe deposits near Perth-Andover revealed no, or only sporadic, trace fossils because of the generally poor exposure and smaller outcrop size, resulting in a deficiency of talus. Secondly, traces are preserved 
toponomically as semireliefs and, for optimum preservation, a contrast in lithology between the excavated and casting sediments is required (Fillion and Pickerill, 1990). In the Wapske Formation, both monolithologic sandstones (lobe deposits and portions of lobe fringe deposits) and shales (basin plain deposits) display the fewest number of trace fossils and a realistic scenario of the ichnocoenoses is difficult to reconstruct. However, couplets of thinly interbedded sandstones and mudstones provide an ideal medium for the preservation of trace fossils and the degree of weathering and talus development in these rock types provide ideal conditions for observations of semirelief traces, such as with the lobe fringe and interchannel deposits.

\section{Conclusions}

The main conclusions that can be drawn from this study are:

(1) The Wapske Formation of the Lower Devonian (Lochkovian-Pragian) Tobique Group, located between PerthAndover and Mount Carleton, northwestern New Brunswick, possesses seven sedimentary lithofacies that can be organized into five facies associations. These facies associations reflect deposition in distributary channels, depositional lobes, lobe or fan fringes, interchannel and basin plain subenvironments in association with a deep-water submarine fan complex.

(2) A relatively diverse and well-preserved ichnofauna is, to varying degrees, present in these various subenvironments. In total these ichnofaunas include 23 ichnogenera (41 ichnospecies) and three vernacular forms. Their palaeoenvironmental distribution, as determined from facies analysis, suggests close comparisons with other ichnofaunas described from deep-water submarine fan systems. The ichnofauna of the Wapske Formation is, collectively, characteristic of Seilacher's (1967) Nereites ichnofacies. The main primary controlling factors of the ichnofaunal distribution were food supply, oxygen levels, sediment texture, sedimentation rates and frequency of event deposition.

(3) Secondary factors considered important with respect to trace fossil distributions in the various subenvironments of the Wapske Formation include nature and quality of outcrop, such as weathering characteristics, and amount of talus available for detailed analysis.

\section{SYSTEMATIC ICHNOLOGY}

In accordance with common ichnological procedure (Häntzschel, 1975; Pemberton and Frey, 1984; Fillion and Pickerill, 1990), the ichnotaxa in this contribution are described in alphabetical order rather than in any morphological or behavioural classification groupings (e.g., as in Osgood, 1970; Książkiewicz, 1977). This procedure is adopted for ease of reference to a particular ichnotaxon and also because in practice many ichnotaxa may be indicative of more than one behavioural activity. For those ichnotaxa we have previously considered in detail (Han and Pickerill, 1994a,b, 1995), namely Helminthopsis ispp., Phycodes templus and Protovirgularia dichotoma, we only include our previous diagnoses and avoid repetitious descrip- tions. For completeness, however, each of these ichnotaxa are figured herein. Ichnotaxa described in open nomenclature are described separately.

The preservational styles and essential characteristics of each form are listed in Table 3 . Table 4 summarizes the palaeoenvironmental distribution in the sequence. Specimens with prefix TF and TF.F are housed in the Department of Geology, University of New Brunswick, Fredericton, New Brunswick, Canada; the prefix NBMG represents specimens deposited in the Division of Natural Sciences, New Brunswick Museum, Saint John, New Brunswick, Canada.

\section{Ichnogenus Arthraria Billings, 1872}

\section{Type ichnospecies: Arthraria antiquata Billings, 1872 Arthraria antiquata Billings, 1872 Figure 3A}

Material: Four specimens (TF9208-23, TF9208-30, TF921010, TF112).

Description: Dumb-bell shaped traces preserved in convex hyporelief on 26 to $30 \mathrm{~mm}$ thick, grey, parallel-laminated finegrained sandstone or siltstone. Each consists of a shallow and narrow stem connecting two wider and more deeply impressed terminations which are heart-, kidney-, or arrowhead-shaped. The stems are about 3 to $30 \mathrm{~mm}$ long and 2 to $11 \mathrm{~mm}$ wide and terminations 4 to $11 \mathrm{~mm}$ long and 2 to $11 \mathrm{~mm}$ wide. Terminations do not extend upward to form U-shaped tubes and the burrows possess no spreiten.

Remarks: Fillion and Pickerill (1984) reviewed and redefined the monospecific ichnotaxon Arthraria, distinguishing it from the morphologically similar, at least in basal expression, Bifungites Desio, which, however, has vertical tubes without a spreite, and Diplocraterion Torell which has both vertical tubes and a spreite. Arthraria is believed to have been produced by a worm or wormlike organism (Fillion and Pickerill, 1990). Terminations of different shapes may occur in this ichnospecies, even within a single specimen. Size of individual specimens may also vary considerably. Thus all reliable specimens of Arthraria should be included within Arthararia antiquata (Fillion and Pickerill, 1984).

\section{Ichnogenus Bergaueria Prantl, 1945}

\section{Type ichnospecies: Bergaueria perata Prantl, 1945}

The ichnotaxonomy of single-entrance, plug-shaped, softsubstrate trace fossils has been reviewed in detail by Pemberton et al. (1988). By its much larger diameter/height ratio, Bergaueria can be distinguished from Conichnus Myannil, Dolopichnus Alpert and Moore and Conostichus Lesquereux by its lack of a distinct apical disc and wall ornamentation (Pemberton et al., 1988).

Based mainly on characteristics of the distal termination and the presence or absence of wall linings; Pemberton $e t$ al. 

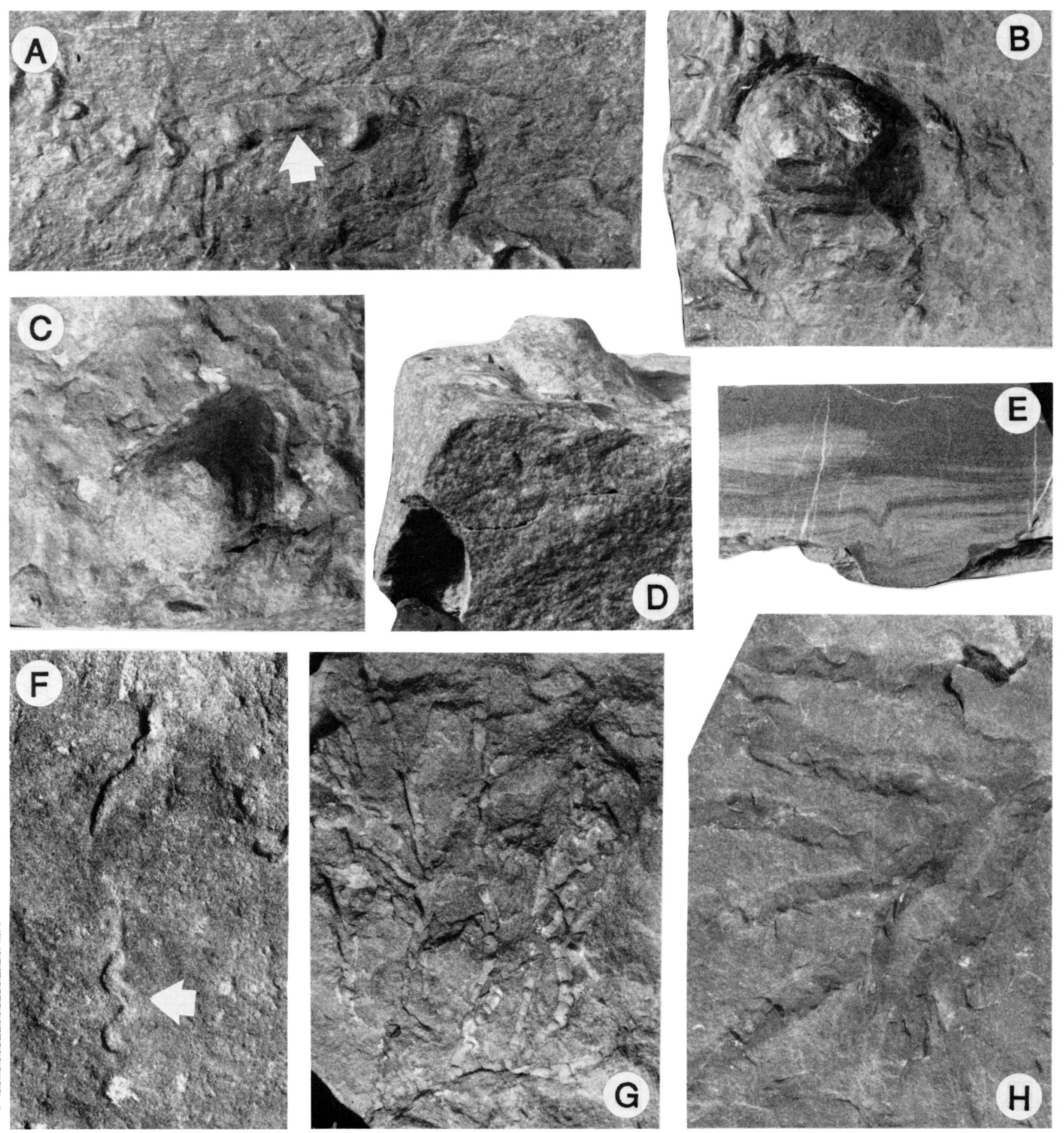

Fig. 3. Trace fossils from the Wapske Formation. (A) Arthraria antiquata (TF9208-23) (arrowed), x 1.14. (B) Bergaueria hemispherica (TF920920), x 0.77. (C, D) Bergaueria aff. perata (TF 9201-21), x 1.0 (C, top view; D, lateral view). (E) Bergaueria hemispherica (TF9208-24), x 0.86 (vertical section showing the V-shaped laminae). (F) Cochlichmus anguineus (TF.F118) (arrowed) intergradational with Helminthopsis isp., $\mathrm{x}$ 1.38. (G) Chondrites furcatus (TF.F223), x 0.83. (H) Chondrites targionii (TF9307-04), $x$ 0.82. A-F are preserved in convex hyporelief; G and $\mathrm{H}$ in endorelief.

(1988) recognized four ichnospecies of Bergaueria, namely, $B$. perata, B. langi (Hallam), B. radiata Alpert and B. hemispherica Crimes, Legg, Marcos and Arboleya. Ethological considerations of these have been discussed by Pemberton et al. (1988) and Pickerill (1989). 
Bergaueria hemispherica Crimes, Legg, Marcos and

Arboleya, 1977

Figure 3B,E

Material: Five specimens (TF9208-24, TF9208-1-13, TF920920, TF.F172, TF.F58).

Description: Vertical, cylindrical to dome-like burrows preserved in convex hyporelief on the soles of 8 to $75 \mathrm{~mm}$ thick, grey, parallel- and cross-laminated siltstone and fine-grained sandstone. The burrows have steeply to gently inclined, unornamented outer margins. The basal surfaces are flat or rounded without typical depressions or ridges. Dimensions are variable. Diameter is equal to or generally greater than height. The distal ends are 15 to $28 \mathrm{~mm}$ in diameter, the proximal ends 18 to $35 \mathrm{~mm}$, and the heights 8 to $12 \mathrm{~mm}$; the average ratio of diameter/height is between 2.5-1. The burrow-fill is the same as the host rock and no lining is observed in vertical section. However, in one vertically sectioned specimen, the primary parallel laminae are distorted to a $\mathrm{V}$-shape pointing to the burrow base (Fig. 3E), which has not been described previously.

Remarks: Bergaueria hemispherica differs from $B$. perata and $B$. radiata by the absence of a central depression and radial ridges and from $B$. lang $i$ by the absence of a thick burrow wall (Pemberton et al., 1988).

\section{Bergaueria aff. perata Prantl, 1945 Figure 3C,D}

\section{Material: One specimen (TF9201-21).}

Description: Hemispherical burrow preserved in convex hyporelief on the sole of a $29 \mathrm{~mm}$ thick siltstone. The burrow has a smooth, unornamented, gently inclined outer wall and a flat apical base which has a circular depression. In plan view, the specimen is circular with an upper diameter of $26 \mathrm{~mm}$, a lower diameter of $8.5 \mathrm{~mm}$, and a height of $12 \mathrm{~mm}$. The base of the specimen is flat, symmetric and possesses a small depression, 3 to $3.5 \mathrm{~mm}$ in width. The burrow-fill is massive and of the same grain size as the host rock. A thin lining is present.

Remarks: Pickerill (1989) provided an in-depth discussion on this ichnospecies. The present specimen has a flat base with a central depression, but no radial ridges as in $B$. perata to which, however, it is otherwise most comparable. The central depression differentiates it from $B$. hemispherica.

\section{Ichnogenus Chondrites von Sternberg, 1833}

\section{Type ichnospecies: Fucoides antiquus Brongniart, 1828}

Chondrites has previously been interpreted as both a feeding and dwelling burrow and probably indicates a systematic search for food by repeated probing of sediment (Vossler and Pemberton, 1988). Previously proposed tracemakers include a variety of endobenthic deposit feeders such as sipunculids (Simpson, 1957), multitentacled organisms (Taylor, 1967), ver- miform worms (Osgood, 1970; Howard and Frey, 1984), arthropods (Ekdale, 1977), anthoptiloid sea pens (Bradley, 1981) and nematodes (Bromley and Ekdale, 1984; Howard and Frey, 1984; Swinbanks and Shirayama, 1984).

Ichnospecific classification of Chondrites is traditionally based on width of the branches and mode and angle of branching (Ksiażkiewicz, 1977), and has resulted in the description of more than 170 ichnospecies (Chamberlain, 1971), many of which are extremely difficult, if not impossible, to differentiate or may, in fact, be simply ontogenetic variants (Hakes, 1976; Książkiewicz, 1977).

Typically occurring infaunally beneath an oxygen-deficient sea-floor below the sediment-water interface (Bromley and Ekdale, 1984), Chondrites has commonly been regarded as an indicator of dysaerobic or even anoxic conditions (Bandel, 1973; Bromley and Ekdale, 1984, 1986). The presence of Chondrites alone in a sedimentary unit, its burrow diameter and the degree of branching can all be used to interpret changes in environmental parameters (Hakes, 1985; Savrda and Bottjer, 1986).

\section{Chondrites furcatus von Sternberg, 1833 Figure 3G}

\section{Material: Three specimens (TF9211-12, TF.F223, TF.F227).}

Description: The burrow systems are well-preserved in endorelief within greenish grey, fine-grained, 10 to $15 \mathrm{~mm}$ thick, sandstones. The burrows are dendritic, maximum width $95 \mathrm{~mm}$, ramifying symmetrically or asymmetrically at very acute angles, $25^{\circ}$ to $55^{\circ}$, commonly $30^{\circ}$ to $40^{\circ}$. Mostly they bifurcate, but occasionally trifurcate. There are up to 3 or 4 orders of branching. The interval length of branching is irregular, either long or short. At branching sites no expansion is present. Individual branches are cylindrical, horizontal or inclined, straight or curved, but never bend, wind, cross or interpenetrate. Burrow fill is lighter in colour and finer in grain size than the host rock. The burrow-fill is separated into transverse segments, which are individually 2.5 to $5 \mathrm{~mm}$ (commonly $4 \mathrm{~mm}$ ) long and 2 to $2.5 \mathrm{~mm}$ wide. The boundaries of the transverse segments are either straight or meniscate without unique form. There is no change in width along the branches.

Remarks: The present specimens are very similar to Chondrites type B of Osgood (1970) and virtually identical to C. furcatus of Książkiewicz (1977) and Crimes and Crossley (1991), and, therefore, are considered conspecific. Chamberlain (1977) regarded $C$. furcatus as a junior synonym of $C$. recurvus Brongniart. However, $C$. furcatus differs from $C$. recurvus by the former's more asymmetrical dichotomous branching pattern and the latter's more symmetrical dichotomous branches which are also more regular and outward curving. Additionally, the present specimens do not exhibit the prominent recurvature characteristic of $C$. recurvus. $C$. furcatus differs from C. targionii (Brongniart) by its curved branches and narrower branching angles and from $C$. intricatus (Brongniart) by its larger size and predominance of asymmetrical dichotomous branching. 
Chondrites targionii (Brongniart, 1828) Figure 3H

Material: Two specimens (TF9307-04, TF115).

Description: The specimens are well-preserved in endorelief in a greater than $50 \mathrm{~mm}$ thick, grey, parallel-laminated, finegrained sandstone. A maximum of five orders of branching are present, resulting in a straight-branched dendritic pattern up to $127 \mathrm{~mm}$ across. The burrow systems are regular, asymmetric and loosely bifurcated. Branches regularly alternately diverge from a "main" stem with branching angles ranging from $30^{\circ}$ to $50^{\circ}$. Branches are straight, 2 to $7 \mathrm{~mm}$ wide, constant or tapering and 7 to $53 \mathrm{~mm}$ long. Burrow fill is black mudstone which is finer in grain size and darker in colour than the host matrix.

Remarks: The present specimens are regarded as Chondrites targionii, because they show a dendritic branching pattern, strong or slender, straight, uniformly wide or slightly tapering branches, and angular branching patterns. It differs from $C$. furcatus, $C$. intricatus and $C$. recurvus by its straighter branches, and from $C$. intricatus by its larger size, smaller branching angles, and possession of asymmetrical dichotomous branches. It also differs from $C$. succulens which is characterized by irregular, nodose, curved to tortuous burrows.

\section{Chondrites isp. form A}

Figure 4B

\section{Material: One specimen (TF9208-43).}

Description: The tiny, tree-like specimen is poorly preserved in convex hyporelief on the surface of a $75 \mathrm{~mm}$ thick, grey, parallel-laminated, fine-grained sandstone. It consists of a very small, horizontal to inclined, symmetrically bifurcated branching system, up to $20 \mathrm{~mm}$ across and possessing two orders of branching. Branching sites have no swelling and are subangular. Branching angles vary between $30^{\circ}$ to $75^{\circ}$. Burrows are slender, straight to slightly wavy, about $1 \mathrm{~mm}$ wide and 3 to $6 \mathrm{~mm}$ long. Branch width is uniform throughout the whole burrow system.

Remarks: The poor and incomplete preservation of the specimen precludes ichnospecific assignment.

\section{Chondrites isp. form B}

Figure 4A

Material: One specimen (TF9211-10).

Description: Fan-shaped burrow system preserved in endorelief within a $20 \mathrm{~mm}$ thick, brown, fine-grained sandstone. It consists of a slender, widely spaced, symmetrically dichotomous branching system, $31 \mathrm{~mm}$ across. The almost straight branches are 0.5 to $1.2 \mathrm{~mm}$ wide and 20 to $50 \mathrm{~mm}$ long, with constant width along individual segments. A maximum of two orders of branching are present. Branching junctions are without swellings and diverge with angles varying from $20^{\circ}$ to $30^{\circ}$. Burrowfill is dark grey mudstone.
Remarks: The poorly preserved and incomplete specimen was found only by splitting the sandstone. Its distinctive fan-like branching system with slender branches distinguishes it from the other ichnospecies of Chondrites described here.

\section{Ichnogenus Cochlichnus Hitchcock, 1858}

Type ichnospecies: Cochlichnus anguineus Hitchcock, 1858 Cochlichnus anguineus Hitchcock, 1858

Figure 3F

\section{Material: One specimen (TF.F118).}

Description: Smooth, unbranched sine-like trail preserved in convex hyporelief on the sole of a $25 \mathrm{~mm}$ thick, brown, finegrained sandstone. The trail, $16 \mathrm{~mm}$ long and $1.5 \mathrm{~mm}$ wide, exhibits a wavelength of $2 \mathrm{~mm}$ and amplitude of $4 \mathrm{~mm}$.

Remarks: Cochlichnus is usually regarded as a repichnion (Hitchcock, 1858; Pieńkowski and Westwalewicz-Mogilska, 1986), but true burrows have also been documented (Webby, 1970; Eagar et al., 1985). It is thought to have been produced by nematodes and annelids (Hitchcock, 1858; Seilacher, 1963; Moussa, 1969, 1970; Hakes, 1976). Elliott (1985) demonstrated the geometric nature of the repeated clothoid curves of Cochlichnus kochi Ludwig, concluding that this enabled efficient propulsion through watery surface muds of an animal with a hydrostatic skeleton.

The present specimen is directly connected to Helminthopsis isp. as a compound specimen (Pickerill, 1994). The regular sine curve changes to an irregularly winding structure presumably as a result of change in the tracemaker's behaviour.

\section{Ichnogenus Cosmorhaphe Fuchs, 1895}

Type ichnospecies: Cosmorhaphe sinuosa Azpeitia Moros, 1933

Cosmorhaphe fuchsi Ksiażkiewicz, 1970

Figure 4C

Material: Three specimens (TF9202-16, TF9208-41, TF9208$1-30)$.

Description: Smooth, unbranched, composite meanders preserved in convex hyporelief on the soles of 40 to $85 \mathrm{~mm}$ thick, grey, massive to parallel-laminated, fine-grained sandstones. The meanders of the first-order are high but wide at the base (wavelength 120 to $250 \mathrm{~mm}$, amplitude 45 to $170 \mathrm{~mm}$, wavelength/amplitude ratio 1.47-2.67). Meanders of the secondorder are very variable, deep or shallow, usually not compressed or constricted, regular to irregular (wavelength 25 to $80 \mathrm{~mm}$, amplitude 5 to $35 \mathrm{~mm}$, wavelength/amplitude ratio changeable, most at least larger than 2.5). The structures are continuous, each with almost a constant diameter of between 1 to $15 \mathrm{~mm}$.

Remarks: The absence of compression and constriction of both the first- and second-order meanders characterizes Cosmorhaphe fuchsi. There are distinct difference between $C$. fuchsi, whose first- and second-order meanders are not compressed, and $C$. 

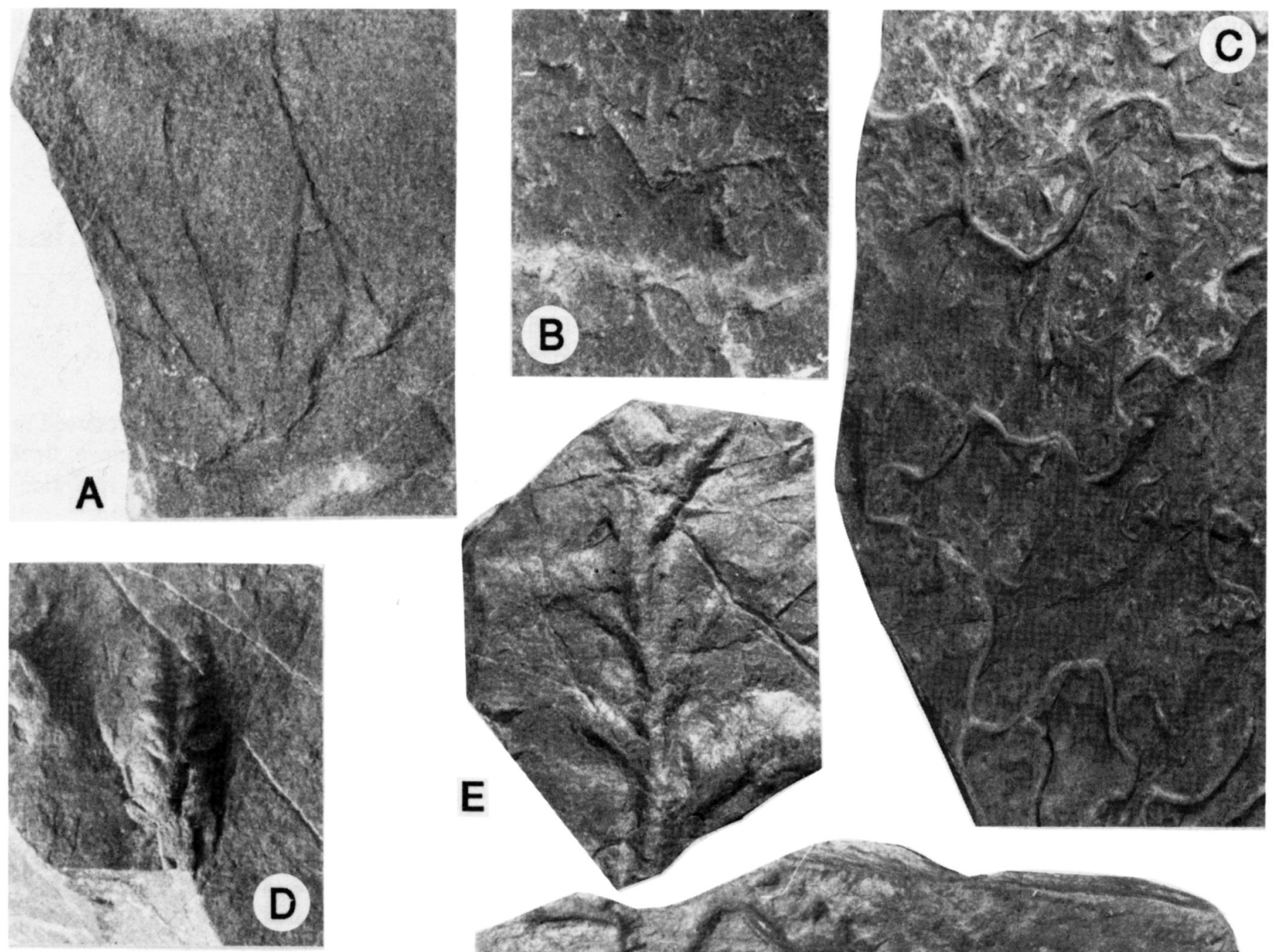

.
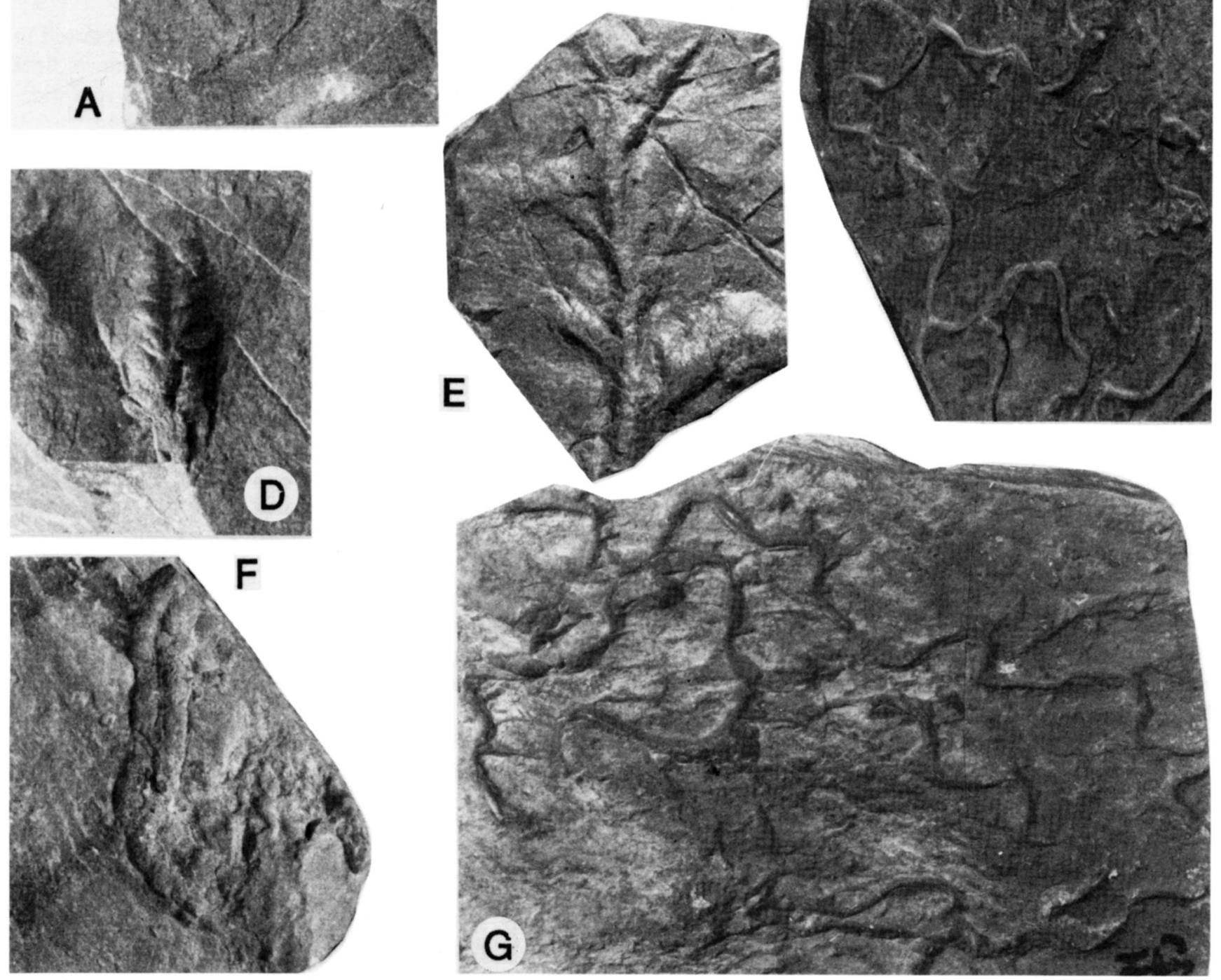

Fig. 4. Trace fossils from the Wapske Formation. (A) Chondriles isp. form B (TF9211-10), x 1.12. (B) Chondrites isp. form A (TF9208-43), $\mathrm{x}$ 1.0. (C) Cosmorhaphe fuchsi (TF9208-1-30), x 0.54. (D) Cruziana problematica (TF9209-18), x 1.93. (E) Dendrotichnium haentzscheli (TF92102-11), x 1.0. (F) Didymaulichnus lyelli (TF9201-13), x 1.12. (G) Cosmorhaphe sinuosa (TF.F142), $x$ 0.74. A is preserved in endorelief; the remainder in convex hyporelief.

sinuosa (Azpeitia Moros), whose first-order meanders are compressed, but whose second-order meanders may or may not be restricted. Cosmorhaphe is a distinctive and typically deep-water flysch form that may be pre- or post-depositional in origin (Ksiażkiewicz, 1977). It may be produced by animals which could live both on the sea-bottom or close to it, as indicated by present day Cosmorhaphe in the deep sea where it is interpreted as an infaunal burrow system positioned just below the sediment surface (Ekdale and Berger, 1978; Ekdale, 1980a, b). It has been interpreted as a grazing trail (Webby, 1969; Häntzschel, 
1975) or a feeding burrow (Seilacher, 1962). Any worm-shaped animal or gastropod without external ornamentation could be responsible for this trace (Książkiewicz, 1977).

\section{Cosmorhaphe sinuosa (Azpeitia Moros, 1933)} Figure 4G

\section{Material: One specimen (TF.F142).}

Description: Smooth, unbranched, composite meanders, $1.8 \mathrm{~mm}$ in diameter, preserved in convex hyporelief on the sole of a 25 $\mathrm{mm}$ thick, parallel-laminated, fine-grained sandstone. The firstorder meanders are narrow and high, 15 to $53 \mathrm{~mm}$ in wavelength and $130 \mathrm{~mm}$ in amplitude. These are superimposed by second-order meanders which range from 25 to $37 \mathrm{~mm}$ in wavelength and 5 to $15 \mathrm{~mm}$ in amplitude. The second-order meanders vary in size within the specimen.

Remarks: Seilacher (1977) suggested that Cosmorhaphe sinuosa can be distinguished from other related forms by the low amplitude of the secondary meanders and the relatively small burrow diameter. Cosmorhaphe sinuosa is related to $C$. helminthopsoida differing only in the latter's less regularly meandering course (Ksiąźkiewicz, 1977).

\section{Ichnogenus Cruziana d'Orbigny, 1842}

\section{Type ichnospecies: Cruziana rugosa d'Orbigny, 1842 Cruziana problematica (Schindewolf, 1921) Figure 4D}

Material: Nine specimens (TF9201-22, TF9209-18, TF.F162, TF.F155).

Description: Specimens are moderately or poorly preserved in convex hyporelief on the soles of 20 to $40 \mathrm{~mm}$ thick, brown or grey, parallel-laminated, fine-grained sandstones. They are straight or slightly curved, 8 to $26 \mathrm{~mm}$ long and 4 to $8 \mathrm{~mm}$ wide, and composed of two lobes (symmetrical or slightly asymmetrical), each 1.8 to $3.5 \mathrm{~mm}$ wide and 0.1 to $1.5 \mathrm{~mm}$ deep, separated by a very shallow median furrow more or less extending the length of the traces. The lobes are characterized by faint or strong, closely spaced transverse or slightly oblique scratch marks which are neither bifid nor bunch together.

Remarks: Lessertisseur (1955) and Osgood (1970) reviewed the origin of Cruziana. It is believed that most were produced by trilobites (Seilacher, 1970) though some may have been produced by trilobite-like arthropods, notostracan branchiopods (Bromley and Asgaard, 1979), aglaspidids (Fisher, 1978) or even vertebrates (Shone, 1978, 1979). Typically a shallow-marine form, Cruziana has also previously been reported from freshwater (Bromley and Asgaard, 1979) and deep-marine (Pickerill et al., 1987) deposits. Cruziana problematica differs from Didymaulichnus Young by the presence of scratch marks on each lobe. It is morphologically identical to the ribbon forms of Isopodichnus Bornemann, though following Bromley and Asgaard (1979), such forms should be regarded as synonyms of
Cruziana (cf. Romano and Whyte, 1987; Pickerill and Peel, 1990; Pickerill, 1994; Keighley and Pickerill, 1995a).

\section{Ichnogenus Dendrotichnium Häntzschel, 1975}

Type ichnospecies: Dendrotichnium llarenai (Farrés, 1967) Dendrotichnium haentzscheli (Farrés, 1967)

Figure 4E

\author{
Material: One specimen (TF92 10-2-11).
}

Description: The specimen comprises a smooth, horizontal burrow system preserved in convex hyporelief on the sole of a grey siltstone. The burrow consists of a central main stem and nearly alternately branched lateral appendages. The burrow system covers a width of $32 \mathrm{~mm}$. The straight main stem is $4 \mathrm{~mm}$ wide and $63 \mathrm{~mm}$ long; the lateral appendages, 3 to $4 \mathrm{~mm}$ wide and 12 to $20 \mathrm{~mm}$ long, branch out obliquely at angles of $30^{\circ}$ to $45^{\circ}$ and are constant in width. The burrow-fill is similar in grain size to the host rock.

Remarks: In contrast to truly dendritic burrow systems such as Chondrites, the side branches of Dendrotichnium may alternate regularly and never show any secondary branches (Seilacher, 1977). Three ichnospecies of Dendrotichnium have been described, namely $D$. haentzscheli, $D$. llarenai and $D$. alternans Seilacher. They are differentiated on the basis of appendage branching angles and patterns and nature of the central stem. Dendrotichnium haentzscheli differs from $D$. llarenai by the latter's right angled branched appendages and from $D$. alternans by the latter's regularly alternately branched lateral appendages and zigzag meandering main stem. Dendrotichnium occurs most commonly in flysch deposits (Seilacher, 1977; Crimes et al., 1981).

\section{Ichnogenus Didymaulichnus Young, 1972}

Type ichnospecies: Fraena lyelli (Rouault, 1850)

Didymaulichnus lyelli (Rouault, 1850)

Figure 4F

\section{Material: One specimen (TF9201-13).}

Description: Narrow and elongate, curved, horizontal bilobate convex hyporelief, 7 to $8 \mathrm{~mm}$ wide and $53 \mathrm{~mm}$ long, preserved on the sole of a maroon siltstone. A distinct median furrow, 0.5 to $1 \mathrm{~mm}$ wide, runs the whole length. The symmetrical lobes have no surface ornament. The specimen undulates slightly in the horizontal plane and therefore the lobe margins are not strictly straight but wavy though still clearly defined. The margins of the lobes are steep, without marginal ridges.

Remarks: The smooth lobes in Didymaulichnus differentiates it from Cruziana which has scratch marks (Young, 1972). It is commonly attributed to gastropods (Glaessner, 1969; Hakes, 1976) or trilobites (Crimes, 1970b; Bradshaw, 1981) and is a facies-crossing form (Young, 1972; Hakes, 1976; Eagar $e$ t al., 1985). As the present specimen is characterized by an absence 
of oblique scratches, lateral ridges, marginal bevels or alternating step-wise compressed sections, it is assigned to Didymaulichnus lyelli.

Ichnogenus Helminthoida Schafhäutl, 1851

Type ichnospecies: Helminthoida labyrinthica Heer, 1865

Seilacher (1977) erected the ichnogenus Helminthorhaphe to include Helminthoida crassa Schafhäutl, H. japonica Tanaka and a new ichnospecies $H$. reflecta. However, Crimes et al., (1981), Crimes and Anderson (1985) and Crimes and Crossley (1991) argued for retention of Helminthoida, their view being accepted, amongst others, by Benton (1982a), McCann and Pickerill (1988), Narbonne and Aitken (1990) as well as herein. Helminthoida is still, however, an ichnogenus that exhibits considerable diversity in form and spacing of its meanders (Ksiażkiewicz, 1977) and course, and there is considerable confusion regarding differentiation of several of its ichnospecies. Recently, Crimes and Crossley (1991) provided a detailed study of Helminthoida and placed $H$. japonica in synonymy with $H$. crassa. They also suggested that more or less regular and closely spaced parallel meanders arranged in a bow-like forms should be included within $H$. crassa, while lower, less compressed meanders and a totally unbowed form with no spiral development should be regarded as $H$. miocenica Sacco. For those with a distinct tendency to coil they suggested accommodation within $H$. labyrinthica. In our experience, this is a workable scheme and is therefore adopted herein. Helminthoida is typically, though not exclusively, a deep-water trace fossil.

\section{Helminthoida cf. labyrinthica Hcer, 1865} Figure 5B

Material: One specimen (TF.F178).

Description: Burrow is preserved in convex hyporelief on the sole of a $23 \mathrm{~mm}$ thick, buff, fine-grained sandstone. The meanders are closely spaced and even partially overlap. The meanders vary in width between 2 to $9 \mathrm{~mm}$ (commonly $6 \mathrm{~mm}$ ); meander height is 35 to $50 \mathrm{~mm}$ and intervals between them 0 to 4 $\mathrm{mm}$. The burrow surface is smooth and burrow-fill is similar in grain size to the enclosing sandstone.

Remarks: The present specimen is only partially complete but is tentatively assigned to $H$. cf. labyrinthica by the presence of tight meanders and its tendency to coil.

\section{Helminthoida miocenica Sacco, 1886}

Figure 5A

Material: Three specimens (TF.F111, TF.F113, TF.F114).

Description: Specimens are preserved in convex hyporelief on the soles of 20 to $27 \mathrm{~mm}$ thick, brown, fine-grained sandstones. The meanders are up to $34 \mathrm{~mm}$ high while the distance between the arms of the meanders is 5 to $14 \mathrm{~mm}$, giving a ratio of height/width between 2-5. The meanders are parallel to each other without a bow-like form or tendency to coil. Most meanders bulge at their turning sites resulting in a horseshoe-like form. The width of the meanders is between 1 to $2 \mathrm{~mm}$, this remaining constant in individual specimens. The surface of the meanders is smooth.

Remarks: These specimens are very similar to descriptions, and criteria for the recognition, of $H$. miocenica by Ksiażkiewicz (1977) and Crimes and Crossley (1991). The meanders of $H$. miocenica are less regular and tighter than in $H$. crassa. Similar bulging meanders can also be observed in Ksiażkiewicz's (1977, p. 166, figs. 36a,d,e) specimens.

\section{Ichnogenus Helminthopsis Heer, 1877}

\section{Type ichnospecies: Helminthopsis magna Heer, 1877 \\ Helminthopsis abeli Książkiewicz, 1977 \\ Figure 5C}

Material: Seven specimens (NBMG 9670 - NBMG 9675, and NBMG 9676 (partim)) and more than 50 specimens collected and many more field occurrences.

Emended diagnosis: Helminthopsis that is loosely winding or meandering. Meanders irregular and variable in shape, mostly deep, but also shallow, with bell-shaped and, or, horseshoeshaped segments, but no straight segments or loops. The axes of the meanders are not parallel. Diameter is variable and generally constant within a single specimen (modified from Książiewicz, 1977).

Description and Remarks: See Han and Pickerill, 1995.

\section{Helminthopsis cf. granulata Ksiązkiewicz, 1968 Figure 5D}

Material: One specimen (NBMG 9682).

Emended diagnosis: Helminthopsis which is variably and irregularly but loosely meandering. Surface is characteristically covered with warts and ridges arranged parallel to its axis (modified from Ksiażkiewicz, 1977).

Description and Remarks: See Han and Pickerill, 1995.

\section{Helminthopsis hieroglyphica Heer in Maillard, 1887} Figure 5F

Material: Six specimens (NBMG 9676 (partim), NBMG 9677 - NBMG 9681) and more than 44 specimens collected and many more field occurrences.

Diagnosis: Helminthopsis in which the windings, normally wide and low, comprise straight segments interspersed with irregularly sinuous and variably developed segments. The tortuous segments may be bell-shaped but not horseshoe-shaped. The full course is commonly, though not exclusively, alternately winding and straight (modified from Książkiewicz, 1977). 

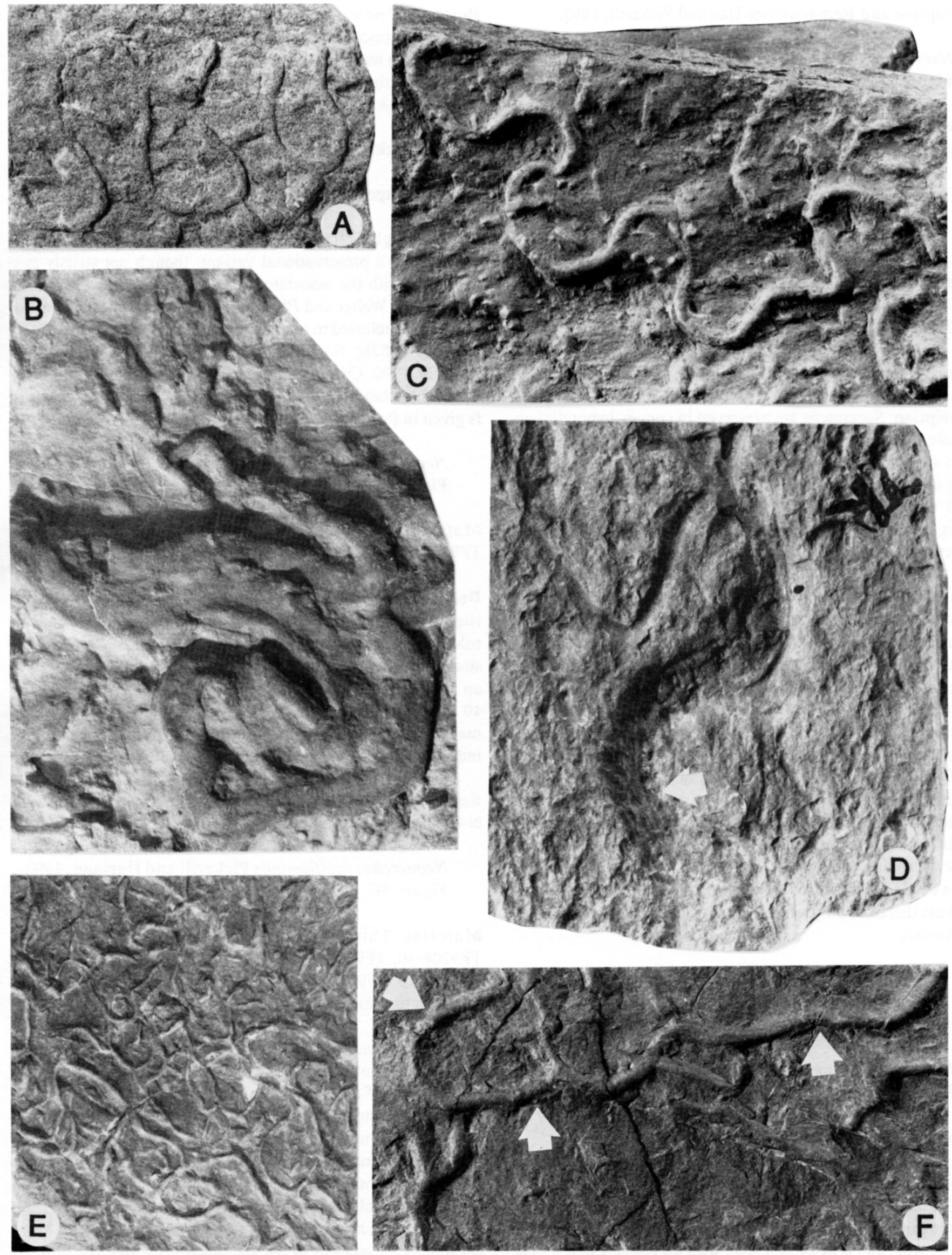

Fig. 5. Trace fossils from the Wapske Formation. (A) Helminthoida miocenica (TF.F111), x 1.64. (B) Helminthoida cf. labyrinthica (TF.F178), $\mathrm{x}$ 1.20. (C) Helminthopsis abeli (NBMG 9675), $x$ 1.19. (D) Helminthopsis cf. granulata (NBMG 9682) (arrowed), $x$ 0.91. (E) Helminthopsis isp. (NBMG 9683), x 0.51. (F) Helminthopsis hieroglyphica (NBMG 9680) (arrowed), x 1.1. All specimens are preserved in convex hyporelief. 
Description and Remarks: See Han and Pickerill, 1995.

\section{Helminthopsis isp. Figure 5E}

Material: One specimen (NBMG 9683) and 67 specimens collected and over one hundred field occurrences.

Description and Remarks: See Han and Pickerill, 1995.

Ichnogenus Hormosiroidea Schaffer, 1928

Type ichnospecies: Hormosiroidea florentina Schaffer, 1928 Hormosiroidea cf. beskidensis (Plička, 1974) Figure 6A

Material: Three specimens (TF.F176, TF.F177, TF.F 209).

Description: Specimens are preserved in convex hyporelief on the sole of a ripple-marked, $30 \mathrm{~mm}$ thick, buff, parallel-laminated siltstone. They consist of two parallel rows of circular or elongate knobs, each 2 to $7 \mathrm{~mm}$ in diameter. Individual rows 10 to $19 \mathrm{~mm}$ apart; the interval between successive individual knobs, 3 to $8 \mathrm{~mm}$, is not constant along the length. The knobs are arranged alternately, in pairs, or irregularly.

Remarks: The nomenclature of Hormosiroidea (and the morphologically similar ichnotaxon Saerichnites Billings) has been discussed by Seilacher (1977) and Crimes and Anderson (1985) and there is little need for further discussion. It is a form that occurs both in deep-water (Seilacher, 1977; Crimes et al., 1981; Crimes and Crossley, 1991) and shallow-water (Frey and Chowns, 1972; Crimes and Anderson, 1985; Walter et al., 1989) marine environments, though mostly in flysch deposits.

Depending on the degree of erosion, Hormosiroidea can exhibit considerable morphological variation (Seilacher, 1977). The alternation of knobs in material from the Wapske Formation is not as well developed as in Plička's (1974) specimen of $H$. beskidensis. Additionally, in some parts of the specimens only a single row of burrow knobs is present. The present specimens are therefore only tentatively identified as Hormosiroidea beskidensis.

\section{Ichnogenus Monomorphichnus Crimes, 1970}

Type ichnospecies: Monomorphichnus bilinearis Crimes, 1970

\section{Monomorphichnus multilineatus Alpert, 1976 Figure 6B}

Material: One specimen (NBMG 9352 (partim)).

Description: Trace preserved in convex hyporelief on the sole of a $13 \mathrm{~mm}$ thick, parallel-laminated, fine-grained sandstone as three to seven parallel, very low, straight ridges or dig marks, $0.5 \mathrm{~mm}$ wide and 6 to $14 \mathrm{~mm}$ long with an interval of $0.4 \mathrm{~mm}$ between adjacent ridges, forming sets 2 to $3 \mathrm{~mm}$ deep and 4 to $6 \mathrm{~mm}$ wide. The central ridges are deeper and of the same width as the lateral ones.
Remarks: The sets of multiple ridges in the present specimen suggest the trace was produced by the digging action of an organism with multidigited appendages. The ridges are well-preserved in only one set which, however, permits confident assignment to Monomorphichnus multilineatus.

Ichnogenus Neonereites Seilacher, 1960

Type ichnospecies: Neonereites biserialis Seilacher, 1960

Although Seilacher and Meischner (1965) considered Neonereites a preservational variant, though not strictly synonymous, with the associated ichnogenera Nereites MacLeay, Scalarituba Weller and Phyllodocites Geinitz, most recent authors have preferred to retain it as a distinctive ichnotaxon (e.g., Benton, 1982b; Narbonne and Aitken, 1990; Fillion and Pickerill, 1990; Crimes and Crossley, 1991). We follow the opinion of these latter authors, more complete reasoning for which is given in Pickerill (1991).

\section{Neonereites biserialis Seilacher, 1960}

Figure 6E

Material: Seven specimens (TF9202-13, TF9206-1-10, TF9208-11, TF9209-10, TF9210-11, TF9210-2-10).

Description: Straight to winding biserial rows of circular to slightly ovate pustules preserved in convex hyporelief on the soles of 23 to $60 \mathrm{~mm}$ thick, grey siltstones or fine-grained sandstones. The two rows are closely spaced or slightly separated by an axial groove. Individual traces are up to $115 \mathrm{~mm}$ long and 10 to $22 \mathrm{~mm}$ wide. Though typically biserial some specimens may have only one or three pustules arranged in places. The individual pustules are 4 to $8 \mathrm{~mm}$ in diameter.

Remarks. The predominant arrangement of the pustules biserially permits assignment to $N$. biserialis.

\section{Neonereites multiserialis Pickerill and Harland, 1988} Figure 6C

Material: Thirteen specimens (TF9201-10, TF9201-11, TF9208-10, TF9208-21, TF9209-11, TF9210-10, TF9210-12, TF9210-13, TF9210a-10, TF.F 100 (partim)) and several occurrences in the field.

Description: Individual specimens comprise three, up to four, rows of interconnected pustules preserved in convex hyporelief on the soles of 12 to $58 \mathrm{~mm}$ thick, grey or brown, parallellaminated siltstones or fine-grained sandstones. The burrows are horizontal, unbranched and longitudinally curved to irregularly sinuous. Individual rows are up to $100 \mathrm{~mm}$ long and 11 to $24 \mathrm{~mm}$ wide. Pustules are smooth and unornamented, spheroidal to ellipsoidal, variable in size ( 3 to $6 \mathrm{~mm}$ in diameter). Individual pustules may occur discretely or be amalgamated. Vertical transverse sections of the specimen show that the pustules are hemispheres. Burrow-fill is massive and similar to the host rock. 

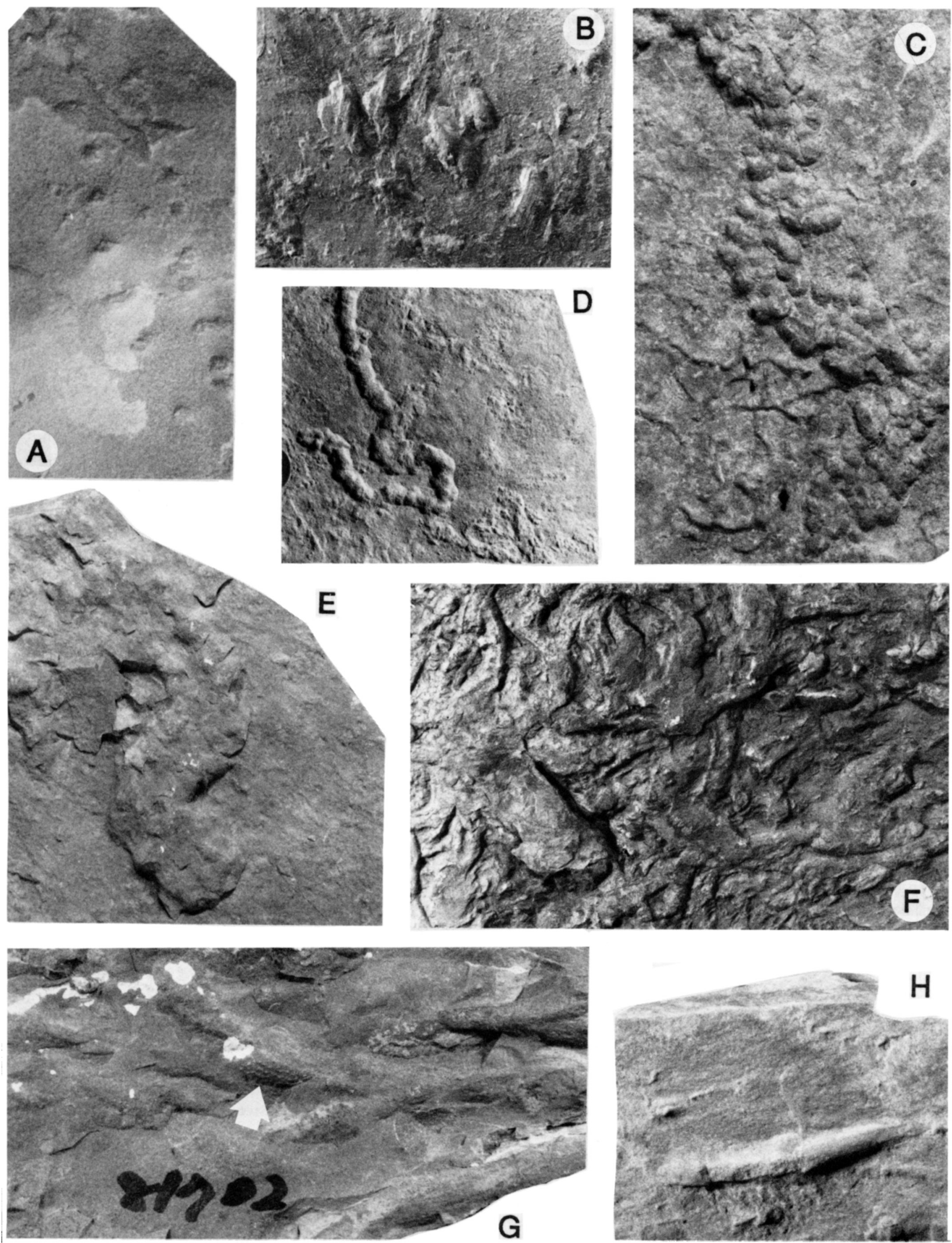

Fig. 6. Trace fossils from the Wapske Formation. (A) Hormosiroidea cf. beskidensis (TF.F177), $x$ 1.0. (B) Monomorphichnus multilineatus (NBMG 9352 (partim)), x 1.0. (C) Neonereites multiserialis (TF9201-11), x 1.11. (D) Neonereites uniserialis (TF.F100), x 1.23. (E) Neonereites biserialis (TF9206-1-10), x 1.0. (F) Palaeophycus heberti (TF.F225), x 0.84. (G) Palaeophycus strialus (arrowed) and Palaeophycus isp. (TF.F218), x 1.0. (H) Palaeophycus tubularis (TF.F129), x 1.0. All specimens are preserved in convex hyporelief. 
Remarks: Pickerill (1991) has discussed this ichnospecies in detail based on material previously collected from the Wapske Formation. Specimens described herein, and more recently collected, support his conclusions.

\section{Neonereites uniserialis Seilacher, 1960 Figure 6D}

Material: Three specimens (TF112, TF.F100 (partim), TF.F103) and several occurrences in the field.

Description: Curved to irregularly winding, uniserial rows of circular to subcircular pustules preserved in convex hyporelief on the soles of 25 to $30 \mathrm{~mm}$ thick, massive or parallel-laminated, siltstones and fine-grained sandstones. Individual rows, up to $730 \mathrm{~mm}$ long, are composed of pustules of 2.5 to $3.5 \mathrm{~mm}$ diameter typically identical throughout their exposed length. Pustules, however, may be connected with Helminthopsis isp. to form a compound specimen. Individual pustules are smooth and closely connected or occasionally mutually overlap.

Remarks: Neonereites uniserialis differs from $N$. biserialis and N. multiserialis in being uniserial and from Microspherichnus linearis Hakes in being preserved in convex hyporelief. The compound (sensu Pickerill, 1994) specimen has not been previously described in the literature. Its occurrence possibly suggests that the individual tracemaker could produce different structures reflecting different behavioural patterns (cf. Bromley, 1990).

\section{Ichnogenus Palaeophycus Hall, 1847}

Type ichnospecies: Palaeophycus tubularis Hall, 1847

The nomenclatural history of Palaeophycus and the morphologically similar ichnotaxon Planolites Nicholson has been recently reviewed by Keighley and Pickerill (1995b). These authors recommended that despite the inherent difficulties, the nomenclatural scheme comprehensively proposed by Pemberton and Frey (1982) is the most workable and, therefore, is that adopted herein (see also Fillion, 1989; Fillion and Pickerill, 1990).

\section{Palaeophycus heberti (de Saporta, 1872) Figure 6F}

Material: Four specimens (TF.F161, TF.F224 (partim), TF.F225 (partim), TF.F226 (partim)) and several occurrences in the field.

Description: Straight to slightly curved, cylindrical to flattened, horizontal, unbranched, smooth-walled, lined burrows, 4 to 11 $\mathrm{mm}$ wide and up to $105 \mathrm{~mm}$ long, preserved in convex hyporelief on $27 \mathrm{~mm}$ thick, greenish grey, buff, cross- to parallel-laminated siltstones and fine-grained sandstones. The well-developed wall-lining is 1 to $2 \mathrm{~mm}$ thick and darker in colour than the burrow-fill which is massive and similar to the host rock. Burrow width remains constant though some burrows exhibit collapse and show central furrows and two narrow walls. Burrows overlap or run alongside each other to create false branching.

Remarks. The present specimens are classified as $P$. heberti based on their characteristic thickly lined, unornamented walls which distinguish this ichnospecies from $P$. tubularis. The lack of any external surface ornamentation distinguishes $P$. heberti from all other ichnospecies of Palaeophycus (Pemberton and Frey, 1982; Frey and Pemberton, 1991).

\section{Palaeophycus striatus Hall, 1852 Figure 6G}

Material: Six specimens (TF9208-1-12, TF9209-19, TF92104-10, TF129, TF.F206, TF.F218 (partim)) and several field occurrences.

Description: Horizontal to slightly inclined unbranched burrows, straight or slightly sinuous, covered with faint, parallel, longitudinal striae, preserved on the soles and in full relief of 35 to $50 \mathrm{~mm}$ thick, greenish grey, grey, buff, parallel-laminated siltstones or fine-grained sandstones. Burrow-fill is massive and similar to the host rock. Longitudinal striae consist of multiple and yet continuously aligned minute circular individual dots. Transverse cross-sections show that the burrows are circular. Burrows are 5 to $19 \mathrm{~mm}$ wide and up to $150 \mathrm{~mm}$ long. Burrow width is generally constant along the length but may swell or narrow in places, especially where entering an interface.

Remarks: The massive burrow-fill suggests that it has not been sorted or processed by the tracemaker. The continuous and longitudinal parallel striae distinguish $P$. striatus from other striate ichnospecies of Palaeophycus (Pemberton and Frey, 1982).

\section{Palaeophycus tubularis Hall, 1847 Figure 6H}

Material: Fourteen specimens (TF9201-14, TF9201-19, TF9201-20, TF9202-14, TF9209-19, TF129, TF.F126-TF.F129, TF.F164-TF.F167) and many more occurrences in the field.

Description: The burrows are preserved in convex hyporelief on the soles of, or in endorelief within, 25 to $50 \mathrm{~mm}$ thick, buff, brown, grey, parallel- or cross-laminated siltstones and finegrained sandstones. The burrows are unbranched, straight to slightly curved, horizontal to undulatory, cylindrical, elliptical or flattened, 4 to $12 \mathrm{~mm}$ in diameter and up to $120 \mathrm{~mm}$ long. Wall-lining, where preserved, is thin; burrow-fill is similar to host rock and typically massive. Burrow surfaces are typically smooth.

Remarks: These morphologically simple burrows are assigned to $P$. tubularis despite the fact that the burrow linings are difficult to detect. Thin wall-linings are easily removed by weathering, commonly resulting in seemingly unlined burrows, which, nevertheless, should be assigned to this ichnospecies. 
Palaeophycus isp. Figure 6G

Material: Three specimens (TF124, TF9208-42, TF.F218 (partim)) and numerous specimens collected and observed in the field.

Description: Cylindrical to ellipsoidal, seemingly unlined or thinly lined, horizontal to inclined burrows, preserved in convex hyporelief on the soles of, or endorelief within, siltstones and fine- to medium-grained sandstones. The straight to slightly curved burrows are 1 to $8 \mathrm{~mm}$ in width and variable in length. Burrow-fill is massive and similar to the host rock.

Remarks: Poor and incomplete preservation, as well as lack of knowledge of the three-dimensional character of the specimens, precludes ichnospecific assignment.

\section{Ichnogenus Paleodictyon Meneghini in Murchison, 1850}

Type ichnospecies: Paleodictyon strozzi Meneghini in Murchison, 1850

Paleodictyon isp.

Figure 7A

Material: Three specimens (TF9208-1-14, TF9208-1-16, TF9208-1-17).

Description: String-sized networks preserved in convex hyporelief on the soles of 26 to $60 \mathrm{~mm}$ thick, grey, parallellaminated, fine-grained sandstones. The poorly preserved specimens consist of irregular or regular polygons. Though no complete horizontal meshes are present, hexagonal meshes can be inferred. Individual polygons are, diagonally, approximately 25 to $45 \mathrm{~mm}$ in diameter and of the same shape. Strings are cylindrical to subcylindrical and vary in thickness from 2 to $3 \mathrm{~mm}$ depending on height. Strings are characteristically straight and smooth; course change in strings is typically sharp and no vertical outlets are observed.

Remarks: Classification of Paleodictyon at the ichnospecific level is still plagued by different authors adopting different criteria (McCann and Pickerill, 1988; Pickerill, 1990; Crimes and Crossley, 1991). Mesh size, regularity, and thickness of string diameter (Ksiażkiewicz, 1970, 1977) or only mesh shape (Seilacher, 1977) have been considered important in the distinction of ichnospecies. The main problem with each of these schemes is the complete gradation between different net sizes, string diameters and, indeed, net shapes (Crimes and Crossley, 1991). Therefore, a taxonomic revision of the ichnogenus is still warranted (McCann and Pickerill, 1988; Pickerill, 1990; Crimes and Crossley, 1991). The generally incomplete preservation of the material described herein precludes ichnospecific assignment.
Ichnogenus Phycodes Richter, 1850

\author{
Type ichnospecies: Phycodes circinatus Richter, 1853 \\ Phycodes flabellus Miller and Dyer, 1878 \\ Figure 7E
}

Material: Three specimens (TF9207-10, TF.F185, TF.F186).

Description: The burrow systems are preserved in convex hyporelief on the soles of 18 to $28 \mathrm{~mm}$ thick, grey, parallellaminated siltstones and fine-grained sandstones. The specimens are 30 to $40 \mathrm{~mm}$ long, 10 to $25 \mathrm{~mm}$ wide and 2 to $5 \mathrm{~mm}$ deep. The proximal branches are initially parallel and then project out at very acute angles in a flabellate or broomlike fashion. The entire systems are composed of 3 to 7 branches which are 2 to $5 \mathrm{~mm}$ wide. The branches are close to each other, straight to slightly curved. The burrows are faintly annulated and some portions are smooth or covered with small dots. The proximal portion of the burrows consists of a few tunnels. Burrow-fill is similar to the host rock and massive.

Remarks: Osgood (1970) discussed this ichnospecies in detail. It is difficult to generalize on an absolutely distinctive pattern for Phycodes flabellus, because the ichnospecies exhibits much variation in overall shape. P. flabellus differs from the morphologically similar $P$. circinatus Richter by its lack of a spreite, and the presence of a more shallow, flabellate burrow network.

\section{Phycodes palmatus (Hall, 1852) \\ Figure 7H}

Material: Five specimens (TF9208-21, TF9208-22, TF921013, TF9306-5, TF128).

Description: The burrow systems are preserved as horizontal palmate structures, 40 to $55 \mathrm{~mm}$ in overall width, on the soles of 28 to $60 \mathrm{~mm}$ thick, grey, parallel-laminated siltstones and fine-grained sandstones or interlayered sandstones and mudstones. Each consists of a smooth proximal burrow, from which project, at acute angles, two to seven burrows, each 7 to $10 \mathrm{~mm}$ in diameter and 20 to $55 \mathrm{~mm}$ long. The branches, straight or very slightly curved, are close to or depart slightly from each other. Burrow surfaces may be covered by minute tubercles.

Remarks. Specimens described here closely resemble Hall's (1852) syntypes and, accordingly, are assigned to P. palmatus. Although a spreite is not present, the palmate branching pattern is clearly obvious.

\section{Phycodes aff. palmatus (Hall, 1852) \\ Figure 7B}

Material: Seven specimens (TF9209-16, TF9209-22, TF920924, TF9209-25, TF.F187, TF.F204). 

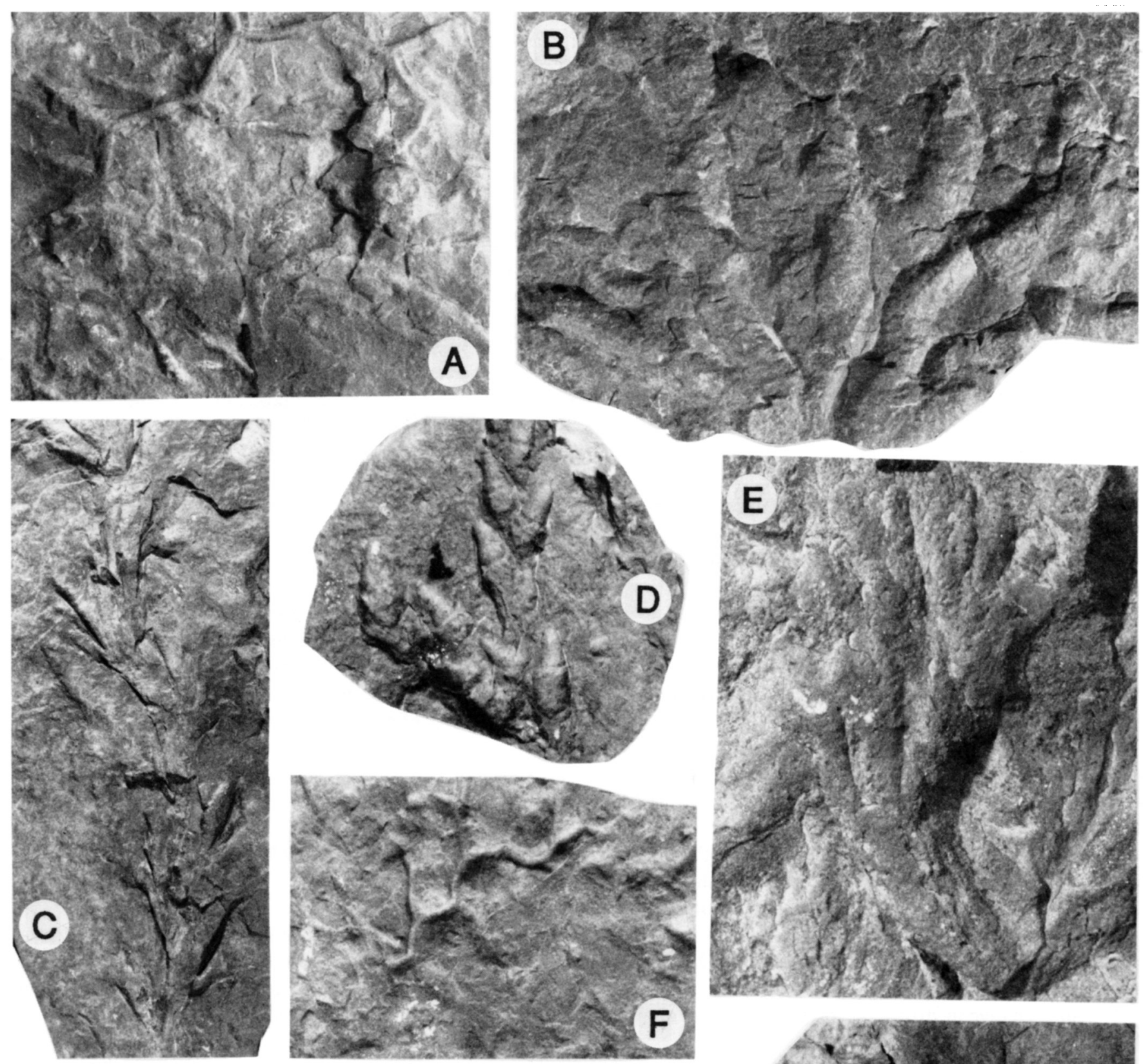

F
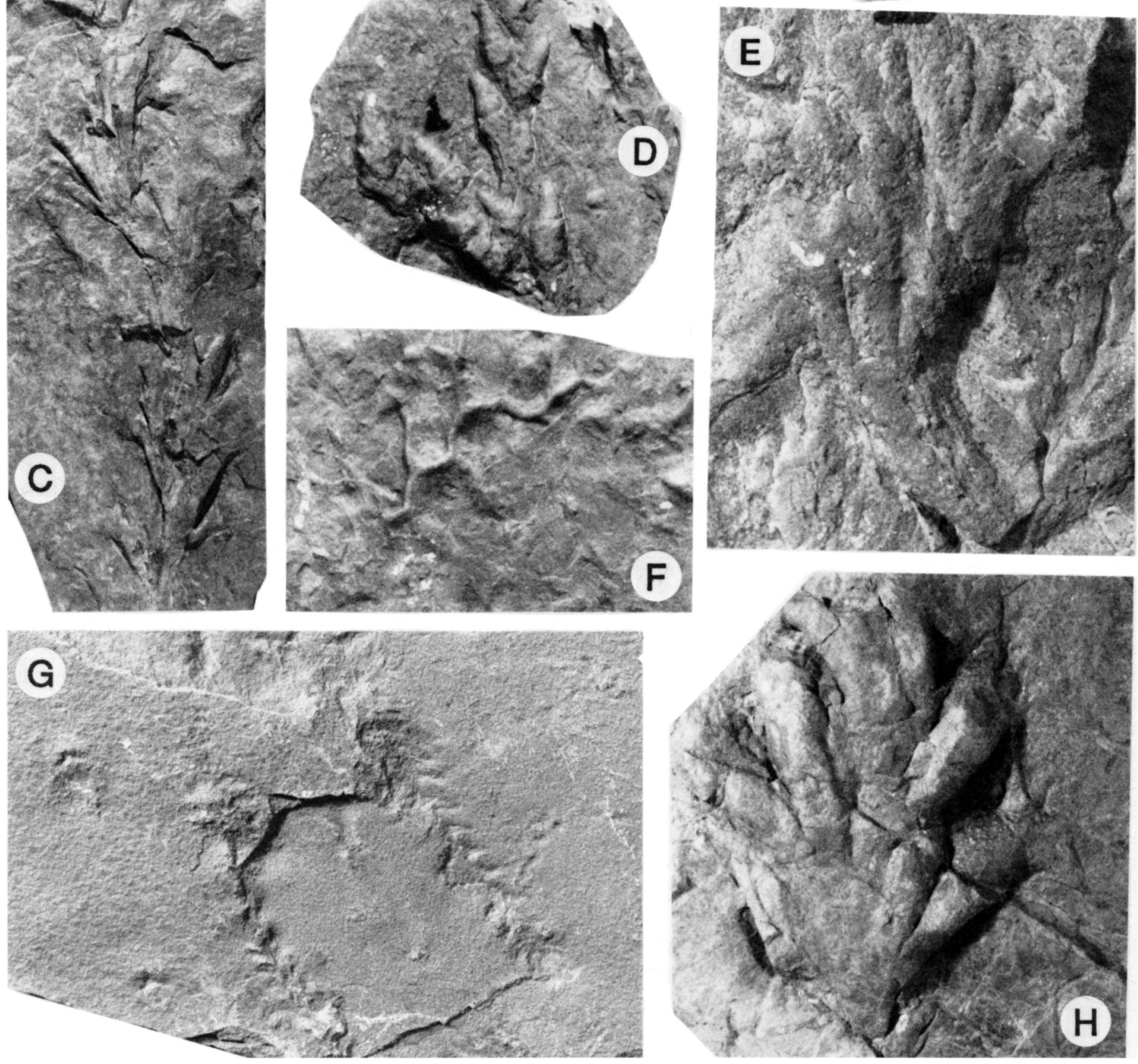
Description: Horizontal burrow systems preserved in convex hyporelief on the soles of 11 to $45 \mathrm{~mm}$ thick, grey, argillaceous siltstones and fine-grained sandstones. The overall pattern of the burrows is thicket-shaped. The systems, 40 to $100 \mathrm{~mm}$ wide and 40 to $80 \mathrm{~mm}$ long, consist of 5 to 8 individual cylindrical branches that project outward from a centre. The proximal portions are not well-preserved or even absent. The branches, smooth, straight or slightly or strongly curved, are 35 to $65 \mathrm{~mm}$ in length and 5.5 to $7 \mathrm{~mm}$ in width which is constant or slightly tapers distally. The elongate branches are closely spaced proximally and widely spaced distally, between 1 and $22 \mathrm{~mm}$ apart (mostly $10 \mathrm{~mm}$ apart).

Remarks. The present specimens differ from typical $P$. palmatus by individual branches being more widely spaced, elongate, strongly curved and lacking a spreite. However, the overall pattern is similar to $P$. palmatus; therefore, the specimens are assigned to $P$. aff. palmatus.

\section{Phycodes pedum Seilacher, 1955}

Figure 7D

Material: Three specimens (TF9210-14, TF102, TF.F191).

Description: Burrow systems preserved in convex hyporelief or full relief on the soles of 19 to $28 \mathrm{~mm}$ thick, grey siltstones and fine-grained sandstones. The burrows consist of a straight row of short, corn-like branches which are of similar size and arranged in a zigzag fashion or closely spaced and bundled in a fan-shape, with branches projecting in a similar direction. No central stem is present. The cylindrical to subcylindrical branches alternately emerge or branch out from the inner side of previous branches at angle of $50^{\circ}$ to $70^{\circ}$ and form a zigzag shape. The surfaces of the branches are transversely ringed with one rounded to subrounded shallow, narrow furrow which cuts the branches into two equal-length parts. The branches, 9 to 11 $\mathrm{mm}$ long and 5 to $6 \mathrm{~mm}$ wide at midlength, taper gradually outward and form sharp terminations. The distal parts of the branches are less deeply impressed than the proximal parts. The incomplete specimens have lengths of 46 to $65 \mathrm{~mm}$ and widths of 8 to $16 \mathrm{~mm}$. Burrow-fill is the same as the host rock. No sickle-like gallery is observed. Cross-cutting reveals that the individual branches are almost on the same plane and mudlined.

Remarks: Phycodes pedum was originally described by Seilacher (1955) as a semicircular form; however, meandering and more or less straight and looping forms have each been subsequently described (Crimes et al., 1977; Bryant and Pickerill, 1990). The minor branches normally all occur on the same side of the main burrow but specimens with one or more on the opposite side to the remainder (Crimes et al., 1977) and even alternating dextral and sinistral branches (Bryant and Pickerill, 1990) have been reported. In the latter case, the branch- ing fashion is similar to that found in the ichnogenus Treptichnus Miller which is probably closely related to Phycodes pedum (Banks, 1970).

\section{Phycodes templus Han and Pickerill, 1994}

Figure 7C

Material: Eight specimens (NBMG 9202 - NBMG 9209) and other collected specimens.

Diagnosis: Phycodes possessing two or, more typically, several horizontally interconnected broomlike or flabellate bundles that collectively form an inverted pagoda-like structure.

Description and Remarks: See Han and Pickerill, 1994a.

Ichnogenus Protopaleodictyon Ksią́kiewicz, 1970

Type ichnospecies: Protopaleodictyon incompositum Ksiażkiewicz, 1970

Protopaleodictyon incompositum Ksią̇ikiewicz, 1970

Figure 7F

Material: One specimen (TF9208-1-15).

Description: Burrow system preserved in convex hyporelief on the sole of a $60 \mathrm{~mm}$ thick, grey, parallel-laminated, fine-grained sandstone. The burrow system consists of wide first-order meanders and sinuous second-order meanders with apical appendages. The first-order meanders are only partially preserved. The appendages are of variable length, 3 to $15 \mathrm{~mm}$, and are positioned on the apices of the second-order meanders and never form a mesh; only one appendix branches from the apex on the convex side of the meanders. The second-order meander have a wavelength of 7 to $16 \mathrm{~mm}$ and amplitude of 2 to $3 \mathrm{~mm}$. The strings, 1.5 to $2 \mathrm{~mm}$ wide, are smooth.

Remarks: Similar to Paleodictyon, there is still no general agreement as to which characters constitute a distinctive ichnospecies of Protopaleodictyon (Pickerill, 1981; Pickerill et al., 1982). Seilacher (1977) utilized the number of branches/ undulations and the presence of first- and second-order meanders, while Ksiażkiewicz (1977) employed the regularity and spacing of the first-order meanders, and the size and thickness of the strings. Ksiażkiewicz's (1977) scheme is that adopted herein in view of the obvious variability exhibited in the specimens figured by him. The ichnogenus has been ascribed to a burrowing deposit feeder, possibly an infaunal annelid (Tanaka, 1971; Kern, 1980; Pickerill, 1981).

The specimen from the Wapske Formation rarely shows first-order meanders, but the second-order meanders, typically with apical appendages, differentiates it from Cosmorhaphe. $P$. incompositum is distinguished from the morphologically similar ichnospecies $P$. minutum Ksiażkiewicz by its larger size and

Fig. 7. Trace fossils from the Wapske Formation. (A) Paleodictyon isp. (TF9208-1-17), x 0.68. (B) Phycodes aff. palmatus (TF9209-22), $x$ 1.22. (C) Phycodes templus (NBMG 9202), x 0.60. (D) Phycodes pedum (TF102), x 1.06. (E) Phycodes flabellus (TF.F186), $\times 2.28$. (F) Protopaleodictyon incompositum (TF9208-1-15), x 1.0. (G) Protovirgularia dichotoma (NBMG9348 (right one) and NBMG 9349 (left one), $x 0.82$. (H) Phycodes palmatus (TF9208-21), x 1.22. All specimens are preserved in convex hyporelief. 
from P. submontanum (Azpeitia Moros) by its more regular meander pattern of the first-order meanders and also by the latter's much longer appendages and a more pronounced tendency toward formation of networks.

\section{Ichnogenus Protovirgularia M'Coy, 1850}

\section{Type ichnospecies: Protovirgularia dichotoma M'Coy, 1850 Protovirgularia dichotoma M'Coy, 1850 \\ Figure 7G}

Material: Nineteen specimens (NBMG 9334 - NBMG 9352).

Emended diagnosis: Unbranched, keel-like trail, typically, but not universally, with a median ridge or furrow from where paired, lateral, wedge-shaped appendages, commonly only a few millimetres in length, and of even or variable spacing, originate. Lateral appendages may be normal or at an acute angle to the median ridge or furrow (modified after Volk, 1961; Benton, 1982a).

Description and Remarks. See Han and Pickerill, 1994b.

Ichnogenus Rusophycus Hall, 1852

Type ichnospecies: Rusophycus clavatus Hall, 1852

Rusophycus cf. carbonarius Dawson, 1864

Figure 8A

Material: One specimen (TF9208-1-34).

Description: Small, bilobate bean-like lobes preserved in convex hyporelief on the sole of a $55 \mathrm{~mm}$ thick, grey, parallel-laminated, fine-grained sandstone. The lobes taper very slightly anteriorly. Maximum width is $10 \mathrm{~mm}$, near the mid-length, and tapers to only $2.5 \mathrm{~mm}$. Maximum length is $17 \mathrm{~mm}$, giving a length/width ratio 1.7. The median longitudinal furrow is shallow and narrow, being deepest near the mid-length of the lobes. Surface of the lobes possess very poorly preserved transverse scratch marks, each $1 \mathrm{~mm}$ in width.

Remarks: The ichnotaxonomy of small cruzianids and nusophycids has recently been reviewed by Keighley and Pickerill (1995a). Although poorly preserved, the specimen described herein closely resembles $R$. carbonarius and is tentatively identified as such.

\section{Ichnogenus Skolithos Haldeman, 1840}

Type ichnospecies: Fucoides? linearis Haldeman, 1840

Skolithos linearis Haldeman, 1840

Figure 8C

Material: Four specimens (TF9210-4-11, TF9302-01, TF122, TF.F203).

Description: Straight, vertical to slightly inclined, unbranched, cylindrical burrows, 3 to $7.5 \mathrm{~mm}$ in diameter and of uncertain length, preserved in endorelief within 20 to $40 \mathrm{~mm}$ thick, grey, parallel-laminated siltstones or fine-grained sandstones. Burrow walls are either sharp and smooth or indistinct. The burrow-fill is massive and may be finer or coarser in grain size and darker or lighter in colour than the surrounding matrix.

Remarks: Although Alpert's $(1974,1975)$ nomenclatural scheme for the main ichnospecies of Skolithos is still regarded as the most satisfactory (Fillion and Pickerill, 1990), its taxonomy is still in need of revision. With respect to this scheme, specimens from the Wapske Formation are identical to $S$. linearis and are identified accordingly.

\section{Ichnogenus Taenidium Heer, 1877}

Type ichnospecies: Taenidium serpentinum Heer, 1877 Taenidium serpentinum Heer, 1877 Figure 8B

Material: Two specimens (TF.F206, TF.F235).

Description: Unlined, or very thinly mudstone lined, cylindrical serpentiform burrows, possessing a well-spaced arcuate meniscate backfill and preserved in convex hyporelief on the soles of 45 and $75 \mathrm{~mm}$ thick, grey, brown, parallel-laminated, fine-grained sandstones. The burrows are straight or slightly curved, unbranched, $4 \mathrm{~mm}$ wide and $100 \mathrm{~mm}$ long. Terminations are obscure. The outer surfaces are wavy or slightly annulated. The faint annulations appear to correspond to the menisci of the fills. In places where the grey mudstone has been removed by weathering, the inner surfaces are obviously annulated by menisci which are $4 \mathrm{~mm}$ wide and 3.5 to $4 \mathrm{~mm}$ long.

Remarks: The ichnotaxonomy of simple, unbranched meniscate burrows has been reviewed by D'Alessandro and Bromley (1987) and more recently by Keighley and Pickerill (1994). With respect to these revisions the material described herein can confidently be assigned to T. serpentinum. T. cameronensis (Brady) differs by possessing intermeniscate segments distinctly longer than wide, $T$. satanassi D'Alessandro and Bromley possesses only weakly arcuate menisci and an obviously pelleted fill (see D'Alessandro and Bromley, 1987) and T. barretti (Bradshaw) possesses deeply arcuate or hemispherical, tightly packed menisci.

\section{Ichnogenus Uchirites Macsotay, 1967}

Type ichnospecies: Uchirites triangularis Macsotay, 1967 Uchirites implexus Rindsberg, 1994

Figure 8D

Material: Seven specimens (TF9201-15, TF9201-16, TF920711, TF9208-24, TF.F182, TF.F183).

Description: Straight, curved or meandering, triangular, horizontal structures, preserved in convex hyporelief on the soles of 24 to $45 \mathrm{~mm}$ thick, grey, brown or orange, parallel- and crosslaminated siltstones and fine-grained sandstones. Specimens possess a single median crest on the lower (ventral) surface and 

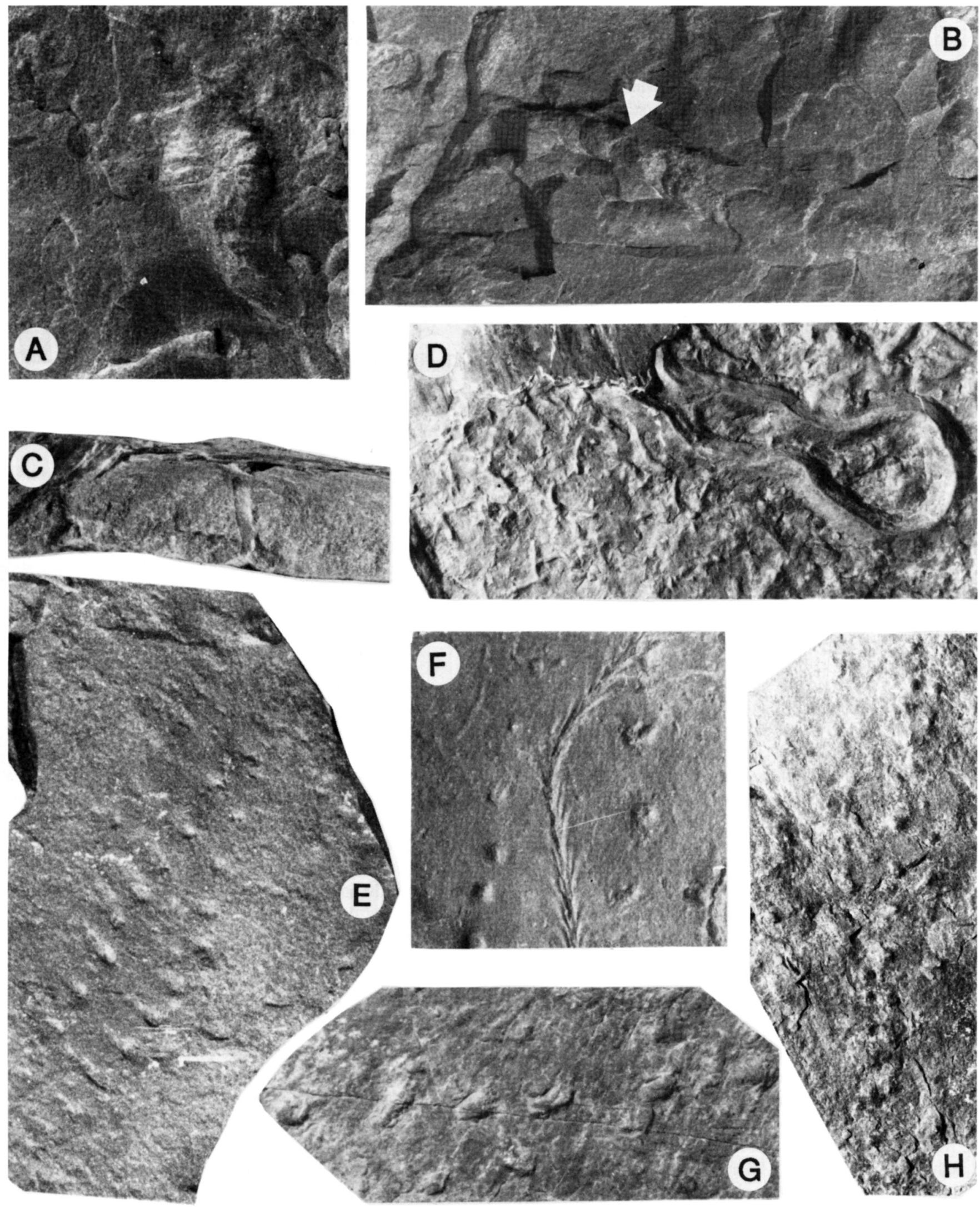

Fig. 8. Trace fossils from the Wapske Formation. (A) Rusophycus cf. carbonarius (TF9208-1-34), x 2.0. (B) Taenidium serpentinum (TF.F206) (arrowed), $x$ 1.63. (C) Skolithos linearis (TF9302-01), x 1.13. (D) Uchiriles implexus (TF.F183), x 0.46. (E) Umfolozia cf. sinuosa (TF.F235), $\mathrm{x}$ 1.61. (F) Track form B (TF9203-11), x 1.11. (G) Scratch marks (TF.F194), x 1.11. (H) Track form A (TF.F210), $x$ 0.97. C is preserved in endorelief; $\mathrm{E}$ in concave relief; remainder in convex hyporelief. 
paired, lateral, smooth marginal flanks. The crests, 1.5 to 2 $\mathrm{mm}$ wide, are typically axial but may be slightly disposed to one side probably as a result of compaction. Structures are 57 to $320 \mathrm{~mm}$ in length and 12 to $15 \mathrm{~mm}$ in width which is constant in single examples. In two specimens, terminations are composed of oval-shaped bulges that lack both the median crest and the inclined lateral lobes but are wider and higher than the main portion of the structures. In one specimen, the median crest terminates $10 \mathrm{~mm}$ before the bulging termination. The fill is similar to or slightly coarser than the surrounding host rock but does not disturb the horizontal laminae in and above the unlined structures.

Remarks: Rindsberg (1994) has recently reviewed the ichnotaxonomy of Uchirites and, in so doing, formulated the ichnospecies $U$. implexus. The present material differs only from his types in the absence of delicate lateral striations, though we regard the absence of these in the Wapske Formation material as preservational. Otherwise, the material is identical and is therefore considered conspecific.

\section{Ichnogenus Umfolozia Savage, 1971}

\section{Type ichnospecies: Umfolozia sinuosa Savage, 1971 \\ Umfolozia cf. sinuosa Savage, 1971 \\ Figure 8E}

Material: Two specimens (TF.F235, TF.F237).

Description: Simple trackways preserved in concave relief, respectively, on the surfaces of 29 and $80 \mathrm{~mm}$ thick, grey, parallel-laminated, fine-grained sandstone and siltstone. The trackways, 55 to $90 \mathrm{~mm}$ long and 8 to $12 \mathrm{~mm}$ wide, consist of two, more or less parallel, straight rows of imprints. Individual imprints, 0.5 to $1 \mathrm{~mm}$ wide and up to $4 \mathrm{~mm}$ long, are arranged approximately in cycles of five and are circular or tadpoleshaped, having a circular deep impression and an elongate shallow or deep tail. The paired imprints are 4 to $9 \mathrm{~mm}$ apart and successive imprints are separated by a distance of 3 to $9 \mathrm{~mm}$. Individual imprints are transverse or oblique to the axial line, oriented at angles of $40^{\circ}$ to $50^{\circ}$. The tails in both rows of trackways are oriented toward the same direction.

Remarks: The significant characteristic of Umfolozia, a trackway suggested by Savage (1971) and Anderson (1981) to have been produced by peracarid crustaceans, is the repetitive nature of the tracks comprising five pairs of appendages and the presence or otherwise of a sinuous series of small oval telson marks (Anderson, 1981). The present samples have a diagnostic track cycle of five, though this is not completely developed along their entire length. Additionally, there are no longitudinal drag lines or drag marks. Nevertheless, we tentatively regard the material as $U$. sinuosa.

Track form A Figure 8H

Material: One specimen (TF.F210).
Description: Trackway preserved in convex hyporelief on the surface of a greenish grey siltstone. The straight trackway consists of two parallel rows or series of circular impressions. It is $120 \mathrm{~mm}$ long and 5 to $6 \mathrm{~mm}$ wide, individual impressions being $1 \mathrm{~mm}$ in diameter and usually 5 to $6 \mathrm{~mm}$ apart in successive rows, rarely $4 \mathrm{~mm}$ apart. The impressions occur commonly in pairs, more rarely dispersed. The area between the two rows is undisturbed.

Remarks: Morphologically, this trackway is similar to examples of Hormosiroidea beskidensis. However, the latter is much larger in size and possesses vertical outlets arranged alternately. The trackway was probably produced by an arthropod-like, bilaterally symmetrical animal.

\section{Track form B \\ Figure 8F}

\section{Material: One specimen (TF9203-11).}

Description: Preserved in convex hyporelief on the sole of a 32 $\mathrm{mm}$ thick, grey, fine-grained sandstone. The trace is composed of two contrasting morphologies, an axial feather-like form and two lateral parallel rows of paired foot or claw imprints appearing as small circular knobs. The whole trace is $62 \mathrm{~mm}$ long and $28 \mathrm{~mm}$ wide.

The slightly curved axial feather-like trail consists of a 'stem' and lateral fine 'filaments'. The 'stem' is 0.5 to $1.0 \mathrm{~mm}$ wide. The fine 'filaments' propagate from the 'stem' and form a V-shape with angles of $16^{\circ}$ to $22^{\circ}$ and individual arms are 0.5 $\mathrm{mm}$ wide and 8 to $10 \mathrm{~mm}$ long. The 'stem' may be formed by overlapping 'filaments'. The axial trail is 4 to $5 \mathrm{~mm}$ wide. The 'filaments' have no branches.

The two rows of foot or claw imprints on each side of the axial trail are roughly parallel and symmetrical. The foot imprints are clear and distinct, circular, large or small, unifid or bifid, and 2 to $4 \mathrm{~mm}$ in diameter with intervals of 4 to $9 \mathrm{~mm}$, up to $11 \mathrm{~mm}$, in a successive row. The distance between rows of imprints and the axial trail is between 5 and $12 \mathrm{~mm}$. The central trail is slightly curved while the lateral rows of imprints remain virtually straight.

Remarks: The axial part of this trackway is similar to both 'Chloephycus' Miller and Dyer (Osgood, 1970, pl. 80, figs. 1, 6) and inorganic groove moulds and chevron marks (Dźulyński and Walton, 1965 , p. 88 , fig. 61 ; p. 100 , figs. $68 \mathrm{~B}, \mathrm{C})$. The present specimen, however, is believed to be biogenic in origin based on the following observations:

(1) The central feather-like marks are curved, unlike typical 'Chloephycus' or inorganic groove markings;

(2) On the same slab, another poorly preserved specimen shows similar feather-like features in which the $\mathrm{V}$-angles point in an opposite direction to the described specimen;

(3) The feather-like marks are flanked by two rows of tracks which are more or less parallel and possess scratches;

(4) Other scratch marks occur on the same stratification surface.

Given a biogenic origin, this trackway does invite com- 
parison with several previously described ichnotaxa. For example, Protovirgularia M'Coy is an ichnotaxon that only has the central feather-like parts. Protichnites Owen has two rows of bifid or trifid imprints which flank the median double straight trails and Mesichnium Gilmore has two parallel rows of footprints with a median row of suboval regularly spaced depressions.

Imprints of this type were probably made by an unknown bilaterally symmetrical arthropod which had vertical appendages resulting in the central feather-like drag marks, and paired feet leaving lateral rows of scratch marks. Assignment to previously described ichnotaxa is, however, considered unwise pending discovery of additional or more informative material.

\section{Scratch marks \\ Figure 8G}

\section{Material: One specimen (TF.F194).}

Description: A series of imprints are preserved in convex hyporelief on the surface of a $33 \mathrm{~mm}$ thick, grey, fine-grained sandstone. The imprints consist of rectangular impressions, individually $3 \mathrm{~mm}$ wide and 5 to $7 \mathrm{~mm}$ long, with a shallow, short furrow on their lower portions. Individual impressions are parallel to each other but all align at $30^{\circ}$ to $35^{\circ}$ with the presumed axis of movement. The specimen is $96 \mathrm{~mm}$ long and 5 to $6 \mathrm{~mm}$ wide, having intervals between successive imprints of 5 to $10 \mathrm{~mm}$.

Remarks: Mikulás (1992) established the ichnogenus Interruptida for similar surface traces interrupted in regular intervals and, indeed, the description, dimensions and illustration of Interruptida indet. B (Mikuláš, 1992, pl. 13, fig. 5) are similar to the present specimen. However, without more material we are reluctant to accept Mikulás's (ibid.) taxonomic decision, as such examples could conceivably represent taphonomic variants of previously established ichnotaxa. As such we retain the specimen in open nomenclature.

\section{ACKNowledgements}

We wish to thank A. Gómez, R. McCulloch and D. Campbell for technical assistance, R. Wilson and L. Fyffe, New Brunswick Department of Natural Resources and Energy, for assistance in defraying fieldwork expenses, and R. Miller, Steinhammer Palaeontology Laboratory, New Brunswick Museum, for providing appropriate repository numbers for several specimens described and/or figured herein. Constructive critiques of the initial manuscript were provided by $\mathrm{H}$. Hofmann and an anonymous reviewer. Financial support for this research was provided by a Natural Sciences and Engineering Council of Canada operating grant to RKP, which is gratefully acknowledged.

ALPERT, S.P. 1974. Systematic review of the genus Skolithos. Journal of Paleontology, 48, pp. 661-669.

1975. Planolites and Skolithos from the Upper PrecambrianLower Cambrian White-Inyo Mountains, California. Joumal of Paleontology, 49, pp. 508-521.
1976. Trilobite and star-like trace fossils from the White-Inyo Mountains, California. Journal of Paleontology, 50, pp. 226-239.

Anderson, A.N. 1981. The Umfolozia arthropod trackways in the Permian Dwyka and Ecca Series of South Africa. Journal of Paleontology, 55, pp. 84-108.

Azpeitia Moros, F. 1933. Datos para es estudio paleontólogico del Flysch de la Costa Cantábrica y de algunos otros puntos de España. Boletin del Instituto Geologico y Minero de España, 53, pp. 1-65.

Bandel, K. 1973. Trace fossils from the Upper Devonian Nehden Siltstone of Wuppertal-Barmen (Nordrhein-Westfalen, Germany). Palaeontographica, Abteilung A, Paläozoologie-Stratigraphie, 142, pp. 156-176.

Banks, N.L. 1970. Trace fossils from the late Precambrian and Lower Cambrian of Finnmark, Norway. In Trace fossils. Edited by T.P. Crimes and J.C. Harper. Geological Journal, Special Issue 3, Seel House Press, Liverpool, pp. 19-35.

Benton, M.J. 1982a. Trace fossils from Lower Palaeozoic ocean-floor sediments of the Southern Uplands of Scotland. Royal Society of Edinburgh Transactions: Earth Sciences, 73, pp. 67-87.

_- 1982b. Dictyodora and associated trace fossils from the Palaeozoic of Thuringia. Lethaia, 15, pp. 115-132.

Billings, E. 1872. On some fossils from the Primordial rocks of Newfoundland. Canadian Naturalist and Quarterly Journal of Science with the Proceedings of the Natural History Society of Montreal, New Series, 6, pp. 465-479.

Boucot, A.J. and WILsON, R.A. 1994. Origin and early radiation of terebratuloid brachiopods: thoughts provoked by Prorensselaeria and Nanothyris. Journal of Paleontology, 68, pp. 1002-1025.

Bradley, J. 1981. Radionereites, Chondrites and Phycodes, trace fossils of anthoptiloid sea pens. Pacific Geology, 15, pp. 1-16.

Bradshaw, M.A. 1981. Paleoenvironmental interpretations and systematics of Devonian trace fossils from the Taylor Group (lower Beacon Supergroup), Antarctica. New Zealand Journal of Geology and Geophysics, 24, pp. 615-652.

Bromley, R.G. 1990. Trace Fossils: Biology and Taphonomy. Unwin Hyman, London, $280 \mathrm{p}$.

Bromley, R.G. and AsgaArd, U. 1979. Triassic freshwater ichnocoenoses from Carlsberg Fjord, east Greenland. Palaeogeography, Palaeoclimatology, Palaeoecology, 28, pp. 3980.

Bromley, R.G. and Ekdale, A.A. 1984. Chondrites: a trace fossil indicator of anoxia in sediments. Science, 224, pp. 872-874.

1986. Composite ichnofabrics and tiering of burrows. Geological Magazine, 123, pp. 59-65.

Bromley, R.G., Pemberton, S.G., and Rahmani, R.A. 1984. A Cretaceous woodground: the Teredolites ichnofacies. Journal of Paleontology, 58, pp. 488-498.

Brongniart, A.T. 1828. Histoire des végétaux fossiles ou recherches botaniques et géologiques sur les végétaux renfermés dans les diverses couches du globe, volume 1. G. Dufour and E. d'Ocagne, Paris, $136 \mathrm{p}$.

Bryant, I.D. and Pickerill, R.K. 1990. Lower Cambrian trace fossils from the Buen Formation of central North Greenland: preliminary observations. Gronlands geologiske Undersegelse Rapport, 147, pp. 44-62.

Chamberlain, C.K. 1971. Morphology and ethology of trace fossils from the Ouachita Mountains, southeast Oklahoma. Journal of Paleontology, 45, pp. 212-246.

1977. Ordovician and Devonian trace fossils from Nevada Bulletin of Nevada Bureau of Mines and Geology, 90, pp. 1-24.

Corbo, S. 1979. Vertical distribution of trace fossils in a turbidite sequence, Upper Devonian, New York State. Palaeogeography, Palaeoclimatology, Palaeoecology, 28, pp. 81-101.

CRIMES, T.P. 1970a. The significance of trace fossils in sedimentology, stratigraphy and palaeoecology, with examples from Lower 
Palaeozoic strata. In Trace fossils. Edited by T.P. Crimes and J.C. Harper. Geological Journal, Special Issue 3, Seel House Press, Liverpool, pp. 101-126.

1970b. Trilobite tracks and other trace fossils from the Upper Cambrian of North Wales. Geological Journal, 7, pp. 47-68.

Crimes, T.P. and Anderson, M.M. 1985. Trace fossils from Late Precambrian-Early Cambrian of southeastern Newfoundland (Canada): temporal and environmental implications. Journal of Paleontology, 59, pp. 310-343.

Crimes, T.P. and CRossley, J.D. 1991. A diverse ichnofauna from Silurian flysch of the Aberystwyth Grits Formation, Wales. Geological Journal, 26, pp. 27-64.

CrImes, T.P. and Fedonkin, M.A. 1994. Evolution and dispersal of deepsea traces. Palaios, 9, pp. 74-83.

Crimes, T.P., LegG, I., Marcos, A., and Arboleya, M. 1977. ?Late Precambrian-low Lower Cambrian trace fossils from Spain. In Trace fossils 2. Edited by T.P. Crimes and J.C. Harper. Geological Journal, Special Issue 9, Seel House Press, Liverpool, pp. 91-138.

Crimes, T.P., Goldring, R., Homewood, P., van Sturjverberg, J., and Winkler, W. 1981. Trace fossil assemblages of deep-sea fan deposits, Gurnigel and Schlieren flysch (Cretaceous-Eocene), Switzerland. Eclogae Geologicae Helvetii, 74, pp. 953-995.

Crimes, T.P., Garcia Hidalgo, J.F., and Poire, D.G. 1992. Trace fossils from Arenig flysch sediments of Eire and their bearing on the early colonisation of the deep sea. Ichnos, 2, pp. 61-77.

D'Alessandro, A. and Bromley, R.G. 1987. Meniscate trace fossils and the Muensteria-Taenidium problem. Palaeontology, 30, pp. 743-763.

Dawson, J.W. 1864. On the fossils of the genus Rusophycus. Canadian Naturalist and Geologist, New Series, 1, pp. 363-367.

DźULYÑskı, S. and WALTON, E.K. 1965. Sedimentary features of flysch and greywackes. Developments in Sedimentology, 7, 274 p.

Eagar, R.M.C., Baines, J.G., Collinson, J.D., Hardy, P.G., Okolo, S.A., and Pollard, J.E. 1985. Trace fossil assemblages and their occurrence in Silesian (Mid- Carboniferous) deltaic sediments of the Central Pennine Basin, England. In Biogenic structures: their use in interpreting depositional environments. Edited by H.A. Curran. Society of Economic Paleontologists and Mineralogists Special Publication, 35, pp. 99-149.

Ekdale, A.A. 1977. Abyssal trace fossils in worldwide deep sea drilling project cores. In Trace fossils 2. Edited by T.P. Crimes and J.C. Harper. Geological Journal, Special Issue 9, Seel House Press, Liverpool, pp. 163-182

1980a. Trace fossils in deep-sea drilling project Leg 58 cores. Initial Reports of the Deep Sea Drilling Project, 58, pp. 601-605. 1980b. Graphoglyptid burrows in modern deep-sea sediments. Science, 207, pp. 304-306.

1985. Paleoecology of the marine endobethos. Palaeogeography, Palaeoclimatology, Palaeoecology, 50, pp. 63-81.

Ekdale, A.A. and Berger, W.H. 1978. Deep sea ichnofacies: modern organism traces on and in pelagic carbonates of the western equatorial Pacific. Palaeogeography, Palaeoclimatology, Palaeoecology, 23, pp. 263-278.

ElLiotT, R.E. 1985. An interpretation of the trace fossil Cochlichnus kochi (Ludwig) from the East Pennine Coalfield of Britain. Proceedings of the Yorkshire Geological Society, 45, pp. 183-187.

FARRÉs, F. 1967. Los “Dendrotichnium” de España. Instituto Geológico y Minero de España. Notas y Comunicaciónes, Boletin, 94, pp. 29-36.

Fillion, D. 1989. Les critères discriminants à l'intérieur du triptyque Palaeophycus-Planolites-Macaronichnus. Essai de synthèse d'un usage critique. Comptes rendus de l'Académie des Sciences de Paris, Série 2, 309, pp. 169-172.

Fillion, D. and PICKerill, R.K. 1984. On Arthraria antiquata Billings,
1872 and its relationship to Diplocraterion Torell, 1870 and Bifungiles Desio, 1940. Journal of Paleontology, 58, pp. 683-696. 1990. Ichnology of the Upper Cambrian? to Lower Ordovician Bell Island and Wabana groups of eastern Newfoundland, Canada. Palaeontographica Canadiana, 7, $119 \mathrm{p}$.

Fisher, W.A. 1978. Trace fossils from the lower Harding Formation (Middle Ordovician), Colorado. In Energy resources of the Denver Basin. Edited by J.D. Pruit and P.E. Coffin. Rocky Mountain Association of Geologists Field Conference, Guidebook for 1978, pp. 191-197.

FREY, R.W. and CHOwNs, T.M. 1972. Trace fossils from the Ringgold Road Cut (Ordovician and Silurian), Georgia. In Sedimentary environments in the Paleozoic rocks of northwest Georgia. Compiled by T.M. Chowns. Georgia Geological Survey Guidebook, 11 , pp. 25-55.

Frey, R.W. and Pemberton, S.G. 1991. The ichnogenus Schaubcylindrichnus: morphological, temporal, and environmental significance. Geological Magazine, 128, pp. 595-602.

FREY, R.W. and SEILACHER, A. 1980. Uniformity in marine invertebrate ichnology. Lethaia, 23, pp. 183-207.

Fuchs, T. 1895. Studien uber Fucoiden und Hieroglyphen. Kaiserliche Akademie der Wissenschaften zu Wien, mathematischnaturwissenschaftliche Klasse Denkschriften, 62, pp. 369-448.

FYFFE, L.R. and FRICKER, A. 1987. Tectonostratigraphic terrane analysis of New Brunswick. Maritime Sediments and Atlantic Geology, 23, pp. 113-122.

Glaessner, M.F. 1969. Trace fossils from the Precambrian and basal Cambrian. Lethaia, 2, pp. 369-393

HAKES, W.G. 1976. Trace fossils and depositional environment of four clastic units, Upper Pennsylvanian megacyclothems, northeast Kansas. University of Kansas Paleontological Contributions, Article 63, pp. $1-46$.

1985. Trace fossils from brackish-marine shales, Upper Pennsylvanian of Kansas, U.S.A. In Biogenic structures: their use in interpreting depositional environments. Edited by H.A. Curran. Society of Economic Paleontologists and Mineralogists Special Publication, 35, pp. 21-35.

HaLDEMAN, S.S. 1840. Supplement to number one of "a monograph of the Limniades, or freshwater univalve shells of North America", containing descriptions of apparently new animals in different classes, and the names and characters of subgenera in Paludina and Anculosa. Philadelphia (?private publication), $3 \mathrm{p}$.

HaLl, J. 1847. Palaeontology of New York. Volume I. Containing descriptions of the organic remains of the Lower Division of the New York System, (equivalent of the Lower Silurian rocks of Europe). C. van Benthuysen, Albany, 338 p.

1852. Palaeontology of New York. Volume II. Containing descriptions of the organic remains of the Lower Middle Division of the New York System, (equivalent in part to the Middle Silurian rocks of Europe). C. van Benthuysen, Albany, 362 p.

HaN, Y. 1995. Sedimentology and ichnology of the Lower Devonian Wapske Formation, northwestern New Brunswick, eastern Canada. Unpublished M.Sc. thesis. University of New Brunswick, Fredericton, New Brunswick, 372 p.

Han, Y. and Pickerill, R.K. 1994a. Phycodes templus isp. nov. from the Lower Devonian of northwestern New Brunswick, eastern Canada. Atlantic Geology, 30, pp. 37-46.

- 1994b. Taxonomic reassessment of Protovirgularia M'Coy 1850 with new examples from the Paleozoic of New Brunswick, eastern Canada. Ichnos, 3, pp. 203-212.

1995. Taxonomic review of the ichnogenus Helminthopsis Heer 1877 with a statistical analysis of selected ichnospecies. Ichnos, 4 , in press.

HĀNTZSCHEL, W. 1975. Trace fossils and problematica. In Treatise on 
Invertebrate Paleontology, Part W, Miscellanea, Supplement I. Edited by C. Teichert. Geological Society of America and University of Kansas Press, Boulder, Colorado and Lawrence, Kansas, pp. W1-W269.

Heer, O. 1864-1865. Die Urwelt der Schweiz. Mit sieben landschaftlichen Bildern, elf Tafeln, einer geologishcen Uebersichtskarte der Schweiz und zahlreichen in den Text eingedruckten Abbildungen. Friedrich Schulthess, Zurich. 622 p. [Part 1 (1864): pp. 1-496, pls. 1-10; Part 2 (1865): pp. 497622, pl. 11.]

HeER, O. 1876-1877. Flora fossilis Helvetiae. Die vorweltliche Flora der Schweiz. Verlag J. Wurster \& Co., Zürich. 182 p. [Parts 1, 2 (1876): pp. 1-90; Parts 3, 4 (1877): pp. 91-182.]

Hrтснсоск, E. 1858. Ichnology of New England. A report on the sandstone of the Connecticut valley, especially its fossil footmarks. W. White, Boston, 220 p.

HowARD, J.D. and FREY, R.W. 1984. Characteristic trace fossils in nearshore to offshore sequences, Upper Cretaceous of east-central Utah. Canadian Journal of Earth Sciences, 21, pp. 200-219.

IRRINKI, R.R. and CrousE, G.W. 1986. Geology of Sisson Branch Reservoir map area $(21 \mathrm{O} / 6)$, New Brunswick. New Brunswick Department of Forests, Mines, and Energy, Mineral Resources Division, Map Report 86-1, 19 p.

KeIGHLEY, D.G. and PICKERILL, R.K. 1994. The ichnogenus Beaconiles and its distinction from Ancorichnus and Taenidium. Palaeontology, 37, pp. 305-337.

- 1995a. Small compound Cruziana, Rusophycus, and related ichnotaxa: the nomenclatural debate and systematic ichnology, with examples from eastern Canada. Ichnos, 4 , in press.

1995b. The ichnotaxa Palaeophycus and Planolites: historical perspectives and recommendations. Ichnos, 3, pp. 301-309.

KERN, J.P. 1980. Origin of trace fossils in Polish Carpathian flysch. Lethaia, 13, pp. 347-362.

KERN, J.P. and WARME, J.E. 1974. Trace fossils and bathymetry of the Upper Cretaceous Point Loma Formation, San Diego, California. Bulletin of Geological Society of America, 85, pp. 893-900.

KsıĄżKıEWICZ, M. 1968. O niektórych problematykach z fliszu Karpat Polskich (Częcz III). Polskiego Towarzystwa Geologicznego w Kraków Rocznik, 38, pp. 3-17.

1970. Observations on the ichnofauna of the Polish Carpathians. In Trace fossils. Ediled by T.P. Crimes and J.C. Harper. Geological Journal, Special Issue 3, Seel House Press, Liverpool, pp. 283-322.

1977. Trace fossils in the flysch of the Polish Carpathians. Palaeontologia Polonica, 36, pp. 1-208.

Lessertisseur, J. 1955. Trace fossiles d'activité animale et leur signification paléobiologique. Société Geologique de France, Mémoire, nouvelle série, 74 , pp. 1-150

MacsotaY, O. 1967. Huellas problemáticas y su valor paleoecológico en Venezuela. Geos, 16, pp. 7-79.

Maillard, G. 1887. Considérations sur les fossiles décrits comme algues. Société Paléontologique de la Suisse, Mémoire, 14, pp. $1-40$.

$\mathrm{McC}_{\mathrm{ANN}}, \mathrm{T}$. and Pickerill, R.K. 1988. Flysch trace fossils from the Cretaceous Kodiak Formation of Alaska. Journal of Paleontology, 62, pp. 330-348.

M'Coy, F. 1850. On some genera and species of Silurian Radiata in the collection of the University of Cambridge. Annals and Magazine of Natural History (Series 2), 6, pp. 270-290.

Mikulás, R. 1992. Trace fossils from the Kosov Formation of the Bohemian Upper Ordovician. Paleontologie, 32, pp. 9-54.

Miller, S.A. and Dyer, C.B. 1878. Contributions to paleontology. Journal of the Cincinnati Society of Natural History, 1, pp. 24-40.

MilLER, W., III. 1991. Intrastratal trace fossil zonation, Cretaceous flysch of northern California. Ichnos, 1, pp. 161-171.
1993. Trace fossil zonation in Cretaceous turbidite facies, northern California. Ichnos, 3, pp. 11-28.

Moussa, M.T. 1969. Nematode fossil tracks of Eocene age from Utah. Nematologica, 15, pp. 376-380.

1970. Nematode fossil trails from the Green River Formation (Eocene) in the Uinta Basin, Utah. Journal of Paleontology, 44, pp. 304-307.

MURCHISON, R.I. 1850. Memoria sulla struttura geologica delle Alpi, delle Apennini e dei Carpazi. Stamperia granucale, Firenze, 528 p.

MutTI, E. and Ricci LucchI, F. 1972. Le torbiditi dell' Appennino settentrionole: introduzione all'analisi di facies. Memories della Societa Geologica Italiana, 11, pp. 161-199.

Narbonne, G.M. and AitKen, J.D. 1990. Ediacaran fossils from the Sekwi Brook area, Mackenzie Mountains, northwestern Canada. Palaeontology, 33, pp. 945-980.

OrbignY, A. D'. 1839/1842. Voyage dans l'Amérique méridionale - le Brésil, la république orientale de l'Uruguay, la république Argentine, la Patagonie, la république du Chili, la république de Bolivia, la république du Pérou - exécuté pendant les années 1826 , $1827,1828,1829,1830,1831,1832$ et 1833 , Paléontologie. PitoisLeverault, Paris; Ve. Leverault, Strasbourg. [1839 = 7 plates only; $1842=$ Tome $3,4 \mathrm{e}$ partie, $188 \mathrm{p}$.]

OsGood, R.G., JR. 1970. Trace fossils of the Cincinnati area. Palaeontographica Americana, 6, pp. 277-444.

Pemberton, S.G. and FreY, R.W. 1982. Trace fossil nomenclature and the Planolites-Palaeophycus dilemma. Journal of Paleontology, 56, pp. 843-881.

-1984. Ichnology of storm-influenced shallow marine sequence: Cardium Formation (Upper Cretaceous) at Seebe, Alberta. In The Mesozoic of middle North America. Edited by D.F. Stott and D.J. Glass. Canadian Society of Petroleum Geologists Memoir, 9, pp. 281-304.

Pemberton, S.G., Frey, R.W., and Bromley, R.G. 1988. The ichnotaxonomy of Conostichus and other plug-shaped ichnofossils. Canadian Journal of Earth Sciences, 25, pp. 866-892.

Pickerill, R.K. 1980. Phanerozoic flysch trace fossil diversity-observations based on an Ordovician flysch ichnofauna from the Aroostook-Matapedia Carbonate Belt of northern New Brunswick. Canadian Journal of Earth Sciences, 17, pp. 1259-1270.

- 1981. Trace fossils in a Lower Palaeozoic submarine canyon sequence-the Siegas Formation of northwestern New Brunswick, Canada. Maritime Sediments and Atlantic Geology, 17, pp. 3758.

- 1986. Stratigraphy, sedimentology and structural analysis of the geology of the Tobique Reserve Lands with an economic assessment of its geologic resources. Unpublished Report to the Department of Indian and Northern Affairs, Ottawa, Ontario, 61 p.

1987. Late Ordovician sedimentary rocks and trace fossils of the Aroostook-Matapedia Carbonate Belt at Runnymede, Restigouche River, northern New Brunswick. In Centennial Field Guide 5 - Northeastern Section of the Geological Society of America. Edited by D.C. Roy, pp. 385-388.

- 1989. Bergaueria perata Prantl, 1945 from the Silurian of Cape George, Nova Scotia. Atlantic Geology, 25, pp. 191-197.

1990. Nonmarine Paleodictyon from the Carboniferous Albert Formation of southern New Brunswick. Atlantic Geology, 26, pp. 157-163.

1991. The trace fossil Neonereites multiserialis Pickerill and Harland, 1988 from the Devonian Wapske Formation, northwest New Brunswick. Atlantic Geology, 27, pp. 119-126.

1994. Nomenclature and taxonomy of invertebrate trace fossils. In The Palaeobiology of Trace Fossils. Edited by S.K. Donovan. John Wiley \& Sons, Chichester, pp. 3-42. 
Pickerull, R.K. and Harland, T.L. 1988. Trace fossils from Silurian slope deposits, North Greenland. Gronlands geologiske Undersogelse Rapport, 137, pp. 119-133.

Pickerill, R.K. and PeEl, J.S. 1990. Trace fossils from the Lower Cambrian Bastion Formation of North-East Greenland. Gronlands geologiske Undersøgelse Rapport, 147, pp. 5-43.

Pickerill, R.K., Hurst, J.M., and Surlyk, F. 1982. Notes on Lower Palaeozoic trace fossils from Hall Land and Peary Land, North Greenland. In Palaeontology of Greenland: Short Contributions. Edited by J.S. Peel. Gronlands geologiske Undersøgelse Rapport, 108, pp. 25-29.

Pickerill, R.K., Fillion, D., and Harland, T.L. 1984. Middle Ordovician trace fossils in carbonates of the Trenton Group between Montreal and Quebec City, St. Lawrence Lowland, eastern Canada. Journal of Paleontology, 58, pp. 416-439.

Pickerill, R.K., FyfFe, L.R., and Forbes, W.H. 1987. Late OrdovicianEarly Silurian trace fossils from the Matapedia Group, Tobique River, western New Brunswick, Canada. Maritime Sediments and Atlantic Geology, 23, pp. 77-88.

Pieńkowski, G. and Westwalewicz-Mogilska, E. 1986. Trace fossils from the Podhale Flysch Basin, Poland-an example of ecologically-based lithocorrelation. Lethaia, 19, pp. 53-65.

PlıčKa, M. 1974. Saerichnites beskidensis n. sp., a new trace fossil from the Carpathian Flysch of Czechoslovakia. Vesstnik Ústředniho ústavu geologického, 49, pp. 75-81.

PrantL, F. 1945. Two new problematic trails from the Ordovician of Bohemia. Académie Tchèque des Sciences, Bulletin International, Classe des Scienees Mathématiques Naturelles et de la Médecine, 46, pp. 49-59.

Ricci LuCCHI, F. 1975a. Depositional cycles in two turbidite formations of northern Apennines. Journal of Sedimentary Petrology, 45 , pp. $3-43$.

- 1975b. Miocene paleogeography and basin analysis in the Periadriatic Apennines. In Geology of Italy. Edited by C. Squyres. Petroleum Exploration Society of Libya, Tripoli, pp. 129-236.

Richter, R. 1850. Aus der thüringischen Grauwacke. Deutsche Geologische Gesellschaft, Zeitschrift, 2, pp. 198-206.

1853. Gaea von Salfeld. Programm d. Realsch. Saalfeld, pp. 3-32.

RiNDSBERG, A.K. 1994. Ichnology of the Upper Mississippian Hartselle Sandstone of Alabama, with notes on other Carboniferous formations. Bulletin of the Geological Survey of Alabama, 158, pp. 1109.

Romano, M. and Whyte, M.A. 1987. A limulid trace fossil from the Scarborough Formation (Jurassic) of Yorkshires; its occurrence, taxonomy and interpretation. Proceedings of the Yorkshire Geological Society, 46, pp. 85-95.

Rouault, M. 1850. Note préliminaire sur une nouvelle formation découverte dans le terrain silurien inférieur de la Bretagne. Société Géologique de France, Bulletin, série 2, 7, pp. 724-744.

SACCO, F. 1886. Intorno ad alcune impronte organiche dei terreni berziari del piemonte. Academia della Scienze di Torino, Atti, 21, pp. 927-947.

SAPORTA, G., DE. 1872-1873. Paléontologie française ou description des fossiles de la France [commencée par Alcide d'Orbigny et] continuée par une réunion de paléontologistes. Serie 2, Végétaux. Plantes jurassiques, G. Masson, Paris, $506 \mathrm{p}$.

SavaGe, N.M. 1971. A varvite ichnocoenosis from the Dwyka Series of Natal. Lethaia, 4, pp. 217-233.

SAVRDA, C.E. and BotTJER, D.J. 1986. Trace-fossil model for reconstruction of paleo-oxygenation in bottom waters. Geology, 14, pp. 3-6.

SCHAFFER, F.X. 1928. Hormosiroidea florentina nov. gen. nov. sp., ein Fucus aus der Kreide der Umgebung von Florenz. Paläontologische Zeitschrift, 10, pp. 212-215.
SChafHĀUtL, K.F.E. 1851. Geognostiche Untersuchungen des Südbayerischen Alpengebirges. Literatisch-artistische Anstalt, München, $206 \mathrm{p}$.

SchindeWOlF, O.H. 1921. Studien aus dem Marburger Buntsandstein. 1,2. Senckenbergiana, 3, pp. 33-49.

SeILACher, A. 1955. 5. Spuren und Fazies im Unterkambrium. In Beiträge zur Kenntnis des Kambriums in der Salt Range (Pankistan). Edited by O.H. Schindewolf and A. Seilacher. Akademie der Wissenschaften und der Literatur zu Mainz, mathematisch-naturwissen - schaftliche Klasse, Abhandlungen, 10, pp. 373-399.

1960. Lebensspuren als Leitfossilien. Geologische Rundschau, 49, pp. 41-50.

1962. Paleontological studies on turbidite sedimentation and erosion. Journal of Geology, 70, pp. 227-234.

1963. Lebensspuren und Salinitäts-fazies-Symposium zur Unterscheidung mariner und nicht mariner sediments, Düsseldorf 1962. Fortschritte in der Geologie von Rheinland und Westfalen, 10, pp. 81-94.

1967. Bathymetry of trace fossils. Marine Geology, 5, pp. 413428.

1970. Cruziana stratigraphy of "non-fossiliferous" Palaeozoic sandstones. In Trace fossils. Edited by T.P. Crimes and J.C. Harper. Geological Journal, Special Issue 3, Seel House Press, Liverpool, pp. $447-476$.

1977. Pattern analysis of Paleodictyon and related trace fossils. In Trace fossils 2. Edited by T.P. Crimes and J.C. Harper. Geological Journal, Special Issue 9, Seel House Press, Liverpool, pp. 289-334.

SeILACHer, A. and MeIschner, D. 1965. Fazies-Analyse im Paläozoikum des Oslo-Gebietes. Geologische Rundschau, 54, pp. 596-619.

Shone, R.W. 1978. Giant Cruziana from the Beaufort Group. Transactions of the Geological Society of South Africa, 81, pp. 327-329.

1979. "Giant Cruziana from the Beaufort Group". Transactions of the Geological Society of South Africa, 82, pp. 371-375.

Simpson, S. 1957. On the trace fossil Chondrites. Geological Society of London, Quarterly Journal, 112, pp. 475-499.

SkINNER, R. 1982. Geology of the Plaster Rock (east half) map area, New Brunswick. Geological Survey of Canada, Paper 81-8, 16 p.

StERnBERG, K.M., von. 1833. Versuch einer geognostisch-botanischen Darstellung der Flora der Vorwelt, 5, 6. Johann Spurny, Prague, $80 \mathrm{p}$.

St. Peter, C. 1978a. Geology of parts of Restigouche, Victoria, and Madawaska counties, northwestern New Brunswick. New Brunswick Department of Natural Resources, Mineral Resources Branch, Report of Investigation 17,69 p.

1978b. Geology of head of Wapske River, map area J-13 (21 J/ 14). New Brunswick Department of Natural Resources, Mineral Resources Branch, Map Report 78-1, 24 p.

1979. Geology of Wapske-Odell River-Arthurette region, New Brunswick, map areas I-13, I-14, H-14 (parts of $21 \mathrm{~J} / 11,21 \mathrm{~J} / 12$, $21 \mathrm{~J} / 13,21 \mathrm{~J} / 14$ ). New Brunswick Department of Natural Resources, Mineral Resources Branch, Map Report 79-2, 32 p.

- 1981. Geology of North Branch Southwest Miramichi River, map areas J-14, J-15, J-16 (parts of $21 \mathrm{~J} / 11 \mathrm{E}, 21 \mathrm{~J} / 14 \mathrm{E}$ ). New Brunswick Department of Natural Resources, Mineral Resources Branch, Map Report 80-1, 61 p.

1982. Geology of Juniper-Knowlesville-Carlisle area, map areas I-16, I-17, I-18 (parts of $21 \mathrm{~J} / 11,21 \mathrm{~J} / 6$ ). New Brunswick Department of Natural Resources, Mineral Resources Branch, Map Report 82-1, 82 p.

Swinbanks, D.D. and Shirayama, Y. 1984. Burrow stratigraphy in relation to manganese diagenesis in modern deep-sea carbonates. Deep-Sea Research, 31, pp. 1197-1223.

TanakA, K. 1971. Trace fossils from the Cretaceous Flysch of the 
Ikushumbetsu Area, Hokkaido, Japan. Geological Survey of Japan Report, 242, pp. 1-31.

Taylor, B.J. 1967. Trace fossils from the Fossil Bluff Series of Alexander Island. Bulletin of British Antarctic Survey, 13, pp. 130.

UChman, A. 1992. An opportunistic trace fossil assemblage from the flysch of the Inoceramian beds (Campanian-Palaeocene), Bystrica Zone of the Magara Nappe, Carpathians, Poland. Cretaceous Research, 13, pp. 539-547.

Volk, M. 1961. Protovirgularia nereitarum (Reinhard Richter), eine Lebensspur aus dem Devon Thüringen. Senckenbergiana Lethaea, 42, pp. 69-75.

Vossler, S.M. and Pemberton, S.G. 1988. Superabundant Chondrites: a response to storm buried organic material?. Lethaia, 21, p. 94.

WALKER, R.G. and MurTI, E. 1973. Turbidite facies and facies associations. In Turbidites and deep-water sedimentation. Edited by G.V. Middleton and A.H. Bouma. Society of Economic Paleontologists and Mineralogists, Pacific Section, Short Course, Anaheim, California, pp. 119-157.

Walter, R.M., Elphinstone, R., and Heys, G.R. 1989. Proterozoic and Early Cambrian trace fossils from the Amadeus and Georgina Basins, Central Australia. Alcheringa, 13, pp. 209-256.

WebBy, B.D. 1969. Trace fossils (Pascichnia) from the Silurian of New South Wales, Australia. Paläontologische Zeitschrift, 43, pp. 8194.

1970. Late Precambrian trace fossils from New South Wales. Lethaia, 3, pp. 79-109.

WILSON, R.A. 1990. Geology of New Denmark-Salmon River area Victoria County, New Brunswick (parts of NTS J/13, 21J/14, 21O/ 3, 210/4). New Brunswick Department of Natural Resources, Minerals and Energy Division, Report of Investigation 23, 67 p.

Young, F.G. 1972. Early Cambrian and older trace fossils from the southern Cordillera of Canada. Canadian Journal of Earth Sciences, 9, pp. 1-17. 